\title{
Bioactive Natural Antivirals: An Updated Review of the Available Plants and Isolated Molecules
}

\author{
Syam Mohan ${ }^{1, *}$, Manal Mohamed Elhassan Taha ${ }^{1}$, Hafiz A. Makeen ${ }^{2}{ }^{\mathbb{D}}$, Hassan A. Alhazmi ${ }^{1,3}$, \\ Mohammed Al Bratty ${ }^{3}$, Shahnaz Sultana ${ }^{4}$, Waquar Ahsan ${ }^{3}{ }^{(1)}$, Asim Najmi ${ }^{3}$ \\ and Asaad Khalid ${ }^{1}$ \\ 1 Substance Abuse and Toxicology Research Centre, Jazan University, Jazan 45142, Saudi Arabia; \\ mtaha@jazanu.edu.sa (M.M.E.T.); haalhazmi@jazanu.edu.sa (H.A.A.); akahmed@jazanu.edu.sa (A.K.) \\ 2 Department of Clinical Pharmacy, College of Pharmacy, Jazan University, Jazan 45142, Saudi Arabia; \\ hafiz@jazanu.edu.sa \\ 3 Department of Pharmaceutical Chemistry, College of Pharmacy, Jazan University, Jazan 45142, Saudi Arabia; \\ malbratty@jazanu.edu.sa (M.A.B.); wmohammad@jazanu.edu.sa (W.A.); anajmi@jazanu.edu.sa (A.N.) \\ 4 Department of Pharmacognosy, College of Pharmacy, Jazan University, Jazan 45142, Saudi Arabia; \\ shmali@jazanu.edu.sa \\ * Correspondence: smohan@jazanu.edu.sa or syammohanm@yahoo.com
}

Academic Editor: Raphaël E. Duval

Received: 10 September 2020; Accepted: 14 October 2020; Published: 22 October 2020

\begin{abstract}
Viral infections and associated diseases are responsible for a substantial number of mortality and public health problems around the world. Each year, infectious diseases kill 3.5 million people worldwide. The current pandemic caused by COVID-19 has become the greatest health hazard to people in their lifetime. There are many antiviral drugs and vaccines available against viruses, but they have many disadvantages, too. There are numerous side effects for conventional drugs, and active mutation also creates drug resistance against various viruses. This has led scientists to search herbs as a source for the discovery of more efficient new antivirals. According to the World Health Organization (WHO), 65\% of the world population is in the practice of using plants and herbs as part of treatment modality. Additionally, plants have an advantage in drug discovery based on their long-term use by humans, and a reduced toxicity and abundance of bioactive compounds can be expected as a result. In this review, we have highlighted the important viruses, their drug targets, and their replication cycle. We provide in-depth and insightful information about the most favorable plant extracts and their derived phytochemicals against viral targets. Our major conclusion is that plant extracts and their isolated pure compounds are essential sources for the current viral infections and useful for future challenges.
\end{abstract}

Keywords: HIV; HSV; Hepatitis C virus; influenza virus; COVID-19; plant extracts; phytochemicals

\section{Introduction}

A virus is a tiny parasite that has no capacity to replicate itself. Once infected in a host agent or living cell, it produces more viruses using host machinery. With their complexity and diversity, it survives for a long time in the host, bypassing the treatments, and it causes devastating issues such as pandemics [1]. They have RNA or DNA as genetic material with single or double-stranded nucleic acid. Using unique physical properties such as phospholipid layers, ligands, and configurations, they invaded into host cells easily [2]. Viral infections can lead to acute as well as chronic conditions. Acute infections happen in an out of balance way; for instance, it is a non-equilibrium process whereby the virus and host change its process until the destruction of the host or control over the infection. The ineffective function of specific genes related to the immunity of the host or effective reduction 
of host immunity by the viral genes is a niche in this infection and leads to the development of overwhelming consequences [3]. On the other hand, chronic viral infections occur in metastable equilibrium with viral and host genes balancing one another. Sometimes, the virus can persist in the healthy and immune host, which is deprived of any sign of infection [4].

Viral infections and associated diseases are responsible for a substantial number of mortality and public health problems around the world. Each year, infectious diseases kill 3.5 million people worldwide [5]. Even though there are different therapeutic strategies available in the clinical practice, a lack of specificity toward the virus, and the limited efficacy of drugs makes the vaccines a gold standard prophylactic to viral infections. Moreover, the synthetic drugs often do not meet the treatment expectation via either unwanted drug side effects or drug resistance to nucleoside analogues via mutation [6,7]. The drug failure and resistances have led to a growing interest in natural products, especially plants, and investigation into antiviral agent discovery. According to the World Health Organization (WHO), $65 \%$ of the world population is in the practice of using plants and herbs as part of the treatment modality [8]. Human use of plants as medicine, including viral infections, dates back 60,000 years to the Paleolithic age [9]. Hence, plants have an advantage in drug discovery based on their long-term use by humans, and lesser toxicity and plenty of bioactive compounds can be expected from them.

Hence, the aim of the present retrospective review is an update on the discovery regarding different plants and lead compounds isolated from them against the essential and clinically significant virus such as the human immunodeficiency virus (HIV), herpes simplex virus (HSV), influenza, and hepatitis c, clarifying their indication with viruses and mechanisms of action.

\section{Methodology}

To obtain the appropriate literature, we have used relevant keywords such as plants, viruses, phytochemicals, HIV, HSV, influenza, hepatitis-c, HIV integrase, HIV-reverse transcription, HIV-protease, virucidal action, virus replication imbibition, viral attachment, inhibition of hemagglutination, HCV infection replication, etc. These keywords were searched in relevant databases such as Google Scholar, PubMed, Scopus, Scielo, etc. We have collected information from research articles, review articles, PhD theses, books, chapters, and conference abstracts from 1975 to 2020. A total of 207 species have been reported in this review article. The taxonomy of the plant

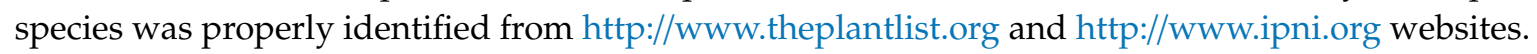

\section{Human Immunodeficiency Virus (HIV)}

The main target of the human immunodeficiency virus (HIV) is our immune system, where it affects and destroys the immune system function. At present, more than 35 million people are suffering from HIV; so far, it caused more than 39 million HIV-related deaths worldwide [10]. The overwhelming adverse effects of HIV continue globally. The treatment for HIV involves antiretroviral therapy (ART), which is a combination of HIV medicines. Since the year 2000, there has been a significant decrease in HIV-related patient deaths, which accounted for about $50 \%$ of all cases. This achievement maybe because of the successful use of ART regimen among the patients and new preventive strategies [11]. Regardless of this progress in HIV treatment with ART and the global measures taken for HIV prevention still, the newly infected HIV patient numbers have been increasing with the rate of 2 million every year [12].

HIV is a member of the genus Lentivirus, part of the family Retroviridae [13]. HIV contains two copies of single-strand RNA, which is the contributory agent of acquired immunodeficiency syndrome (AIDS) by a progressive decline of the immune system. In this condition, the infections take advantage of the weaker immune system, where the immune system is no longer in a stage to fight back. HIV is an enveloped positive-sense virus, which is meticulously focused on the immune system by infecting $\mathrm{CD}^{+} \mathrm{T}$ cells $[14,15]$. This $\mathrm{T}$ helper cell is the core of the immune system, whereby it handles signal transduction toward the rest of the immune cells and thereby protects the whole system against 
life-threatening infections and endangering subjects. The first stage of infection is the attachment of HIV to the $\mathrm{CD}^{+}$lymphoid cell surface. After the viral capsid enters the cell, reverse transcriptase liberates a positive sense single-stranded RNA, coping it into a complementary DNA. Then, the nuclei of host cells become integrated with the viral RNA. The integrated DNA is then transcribed into RNA in the presence of transcription factors such as NF-kB, which is then spliced into messenger RNA (mRNA) [16-18]. Then, the structural protein is generated and made into a new virus particle (Figure 1).

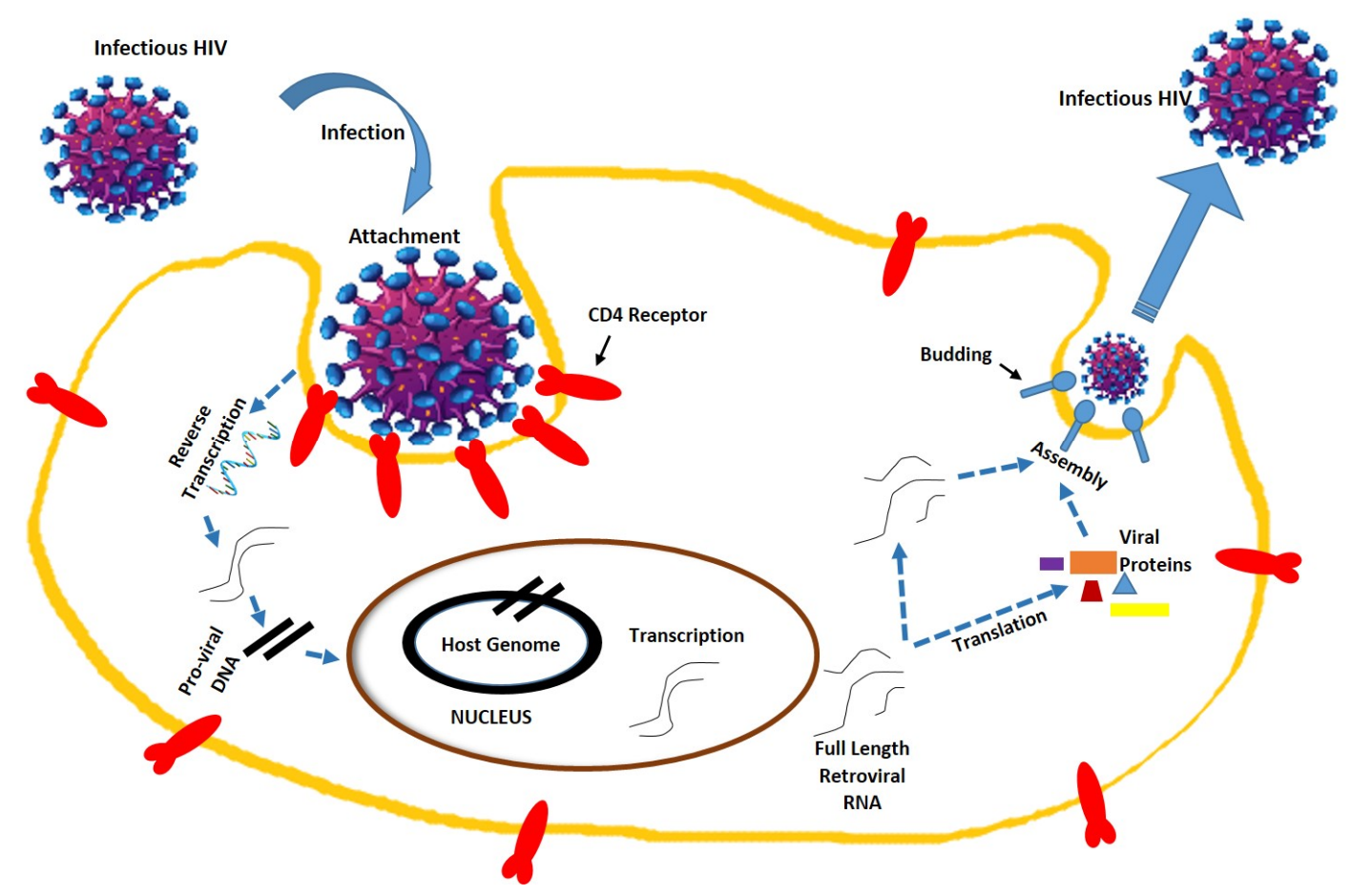

Figure 1. Human immunodeficiency virus structure and replication mechanism. The HIV structure in this figure has been modified from the source www.istockphoto.com.

The antiviral treatments explicitly target these key areas of virus multiplication. Nonetheless, the infection rate of HIV is increasing in spite of ART [19]. Moreover, the ART has become more important, since there is no vaccine available against HIV. However, again, ART is not a panacea for HIV, due to the various side effects and resistance [20,21]. Hence, significant attempts have been employed by natural product biologists to find an alternative for ART. Even the WHO suggests and supports these initiatives. Many plants and plant products such as secondary metabolites have shown significant effects in these targets [22].

Natural products have been explored in finding anti-HIV agents with a critical focus in four mechanisms. They are HIV integrase strand transfer inhibitors [23], Nucleoside Reverse Transcriptase Inhibitors (NRTIs), Nonnucleoside Reverse Transcriptase Inhibitors (NNRTIs), and Protease Inhibitors (PIs) [24]. Integrase is a key enzyme by which HIV inserts (integrate) its viral DNA (proviral) into the DNA of the host CD4 cell. Thus, inhibiting the integrase in the cellular level is a significant target for anti-HIV drug discovery [25]. As per the Food and Drug Administration (FDA), Raltegravir was the first integrase strand inhibitor (INSTI) to be approved in 2007, followed by elvitegravir in 2012 and dolutegravir in 2014. [26]. Natural product discovery has been conducted much time by specifically inhibiting the integrase target [27]. Another target of anti-HIV drugs is reverse transcriptase inhibitors. The reverse transcriptase, a RNA-dependent DNA-polymerase, has been used by the virus to convert RNA to DNA, which is called reverse transcription. Hence, blocking reverse transcription will inhibit HIV replication [28]. In the last phase of viral replication, a viral protease is necessary for the cleavage of a large precursor polyprotein. This cleavage of a 
protein precursor is crucial for the viral particle maturation and infectivity. Saquinavir, indinavir, ritonavir, and nelfinavir are a few examples of approved protease inhibitors by the WHO $[29,30]$. Thus, inhibiting protease is also considered as a significant target of anti-HIV natural products.

In our search for natural products in the mentioned databases, we have observed that the majority of the natural products are evaluated for anti-HIV properties up to the crude extraction level only. So, we found a few major secondary metabolites isolated from plants, which have good activity against HIV. A list of plant species with inhibition studies is summarized in Table 1. 
Table 1. Review of the plants that have shown anti-HIV activities with their prospective family, part, type of extract, and inhibition target.

\begin{tabular}{|c|c|c|c|c|c|c|}
\hline No. & Plant & Family & Part & Extract & Inhibition Target & Ref. \\
\hline 1 & Alchornea laxiflora & Euphorbiaceae & Root & Methanol & HIV integrase & [31] \\
\hline 2 & Mimusops elengi & Sapotaceae & Leaf & Ethanol & HIV integrase & [32] \\
\hline 3 & Sceletium tortuosum & Aizoaceae & Whole plant & Ethanol & HIV integrase & [33] \\
\hline 4 & Hoodia gordonii & Apocynaceae & Whole plant & Ethanol & HIV integrase & [34] \\
\hline 5 & Panax notoginseng & Araliaceae & Whole plant & Methanol & HIV integrase & [35] \\
\hline 6 & Arctium lappa & Asteraceae & Aerial & Methanol & HIV integrase & [35] \\
\hline 7 & Blumea balsamifera & Asteraceae & Whole plant & Ethanol & HIV integrase & [36] \\
\hline 8 & Chrysanthemum indicum & Asteraceae & Capitulum & Methanol & HIV integrase & [35] \\
\hline 9 & Chrysanthemum morifolium & Asteraceae & Capitulum & Ethanol & HIV integrase & [37] \\
\hline 10 & Eclipta prostrate & Asteraceae & Whole plant & Chloroform & HIV integrase & [27] \\
\hline 11 & Senecio scandens & Asteraceae & Whole plant & Methanol & HIV integrase & [34] \\
\hline 12 & Boraginaceae Cordia & Spinescens & Leaf & Methanol, Aqueous & HIV integrase & [38] \\
\hline 13 & Calophyllum inophyllum & Clusiaceae & Bark & Methanol & HIV integrase & [39] \\
\hline 14 & Dioscorea bulbifera & Dioscoreaceae & Whole plant & Methanol & HIV integrase & [40] \\
\hline 15 & Albizia procera & Fabaceae & Whole plant & Methanol & HIV integrase & [35] \\
\hline 16 & Caesalpinia sappan & Fabaceae & Stem & Methanol & HIV integrase & [35] \\
\hline 17 & Agastache rugosa & Lamiaceae & Whole plant & Aqueous methanol & HIV integrase & [41] \\
\hline 18 & Salvia miltiorrhiza & Lamiaceae & Root & Aqueous & HIV integrase & [42] \\
\hline 19 & Lindera aggregate & Lamiaceae & Stem & Methanol & HIV integrase & [43] \\
\hline 20 & Aglaia lawii & Meliaceae & Leaf & Methanol & HIV integrase & [44] \\
\hline 21 & Bersama abyssinica & Melianthaceae & Root & Aqueous & HIV integrase & [45] \\
\hline 22 & Avicennia officinalis & Acanthaceae & Leaf & Methanol & HIV-reverse transcription & [46] \\
\hline 23 & Justicia gendarussa & Acanthaceae & Aerial & Ethanol & HIV-reverse transcription & [47] \\
\hline 24 & Rhinacanthus nasutus & Acanthaceae & Aerial & Hexane & HIV-reverse transcription & [48] \\
\hline 25 & Acorus calamus & Acoraceae & Rhizome & Hexane & HIV-reverse transcription & [48] \\
\hline 26 & Sambucus nigra & Adoxaceae & Whole plant & Methanol & HIV-reverse transcription & [49] \\
\hline 27 & Sambucus racemosa & Adoxaceae & Leaf & Methanol & HIV-reverse transcription & [50] \\
\hline 28 & Aerva lanata & Amaranthaceae & Root & Hexane & HIV-reverse transcription & [51] \\
\hline 29 & Crinum amabile & Amaryllidaceae & Bulb & Methanol & HIV-reverse transcription & [52] \\
\hline 30 & Ancistrocladus korupensis & Ancistrocladaceae & Root & Methanol & HIV-reverse transcription & [53] \\
\hline 31 & Polyalthia suberosa & Annonaceae & Stem & Methanol & HIV-reverse transcription & [47] \\
\hline 32 & Ridolfia segetum & Apiaceae & Whole plant & Essential oil & HIV-reverse transcription & [54] \\
\hline 33 & Hemidesmus indicus & Apocynaceae & Whole plant & Methanol & HIV-reverse transcription & [55] \\
\hline 34 & Tabernaemontana stapfiana & Apocynaceae & Whole plant & Ethanol & HIV-reverse transcription & [56] \\
\hline 35 & Calendula officinalis & Asteraceae & Leaf & Dichloromethane & HIV-reverse transcription & [57] \\
\hline
\end{tabular}


Table 1. Cont.

\begin{tabular}{|c|c|c|c|c|c|c|}
\hline No. & Plant & Family & Part & Extract & Inhibition Target & Ref. \\
\hline 36 & Gamochaeta simplicicaulis & Asteraceae & Whole plant & Pet ether & HIV-reverse transcription & [58] \\
\hline 37 & Lobostemon trigonus & Boraginaceae & Whole plant & Aqueous & HIV-reverse transcription & [59] \\
\hline 38 & Brassica rapa & Brassicaceae & Whole plant & Methanol & HIV-reverse transcription & [60] \\
\hline 39 & Lonicera japonica & Caprifoliaceae & Flower & Ethanol & HIV-reverse transcription & [61] \\
\hline 40 & Gymnosporia buchananii & Celastraceae & Whole plant & Methanol & HIV-reverse transcription & [56] \\
\hline 41 & Salacia chinensis & Celastraceae & Stem & Methanol & HIV-reverse transcription & [48] \\
\hline 42 & Combretum molle & Combretaceae & Root & Aqueous & HIV-reverse transcription & [62] \\
\hline 43 & Ipomoea aquatic & Convolvulaceae & Whole plant & $80 \%$ ethanol & HIV-reverse transcription & [47] \\
\hline 44 & Ipomoea cairica & Convolvulaceae & Aerial & Water & HIV-reverse transcription & [47] \\
\hline 45 & Ipomoea carnea & Convolvulaceae & Aerial & Water & HIV-reverse transcription & [47] \\
\hline 46 & Chamaesyce hyssopifolia & Euphorbiaceae & Whole plant & Methanol & HIV-reverse transcription & [38] \\
\hline 47 & Acalypha Indica & Euphorbiaceae & Whole plant & Methanol & HIV-reverse transcription & [63] \\
\hline 48 & Euphorbia polyacantha & Euphorbiaceae & Whole plant & Aqueous & HIV-reverse transcription & [52] \\
\hline 49 & Mallotus philippensis & Euphorbiaceae & Flower & Methanol & HIV-reverse transcription & [48] \\
\hline 50 & Bauhinia variegata & Fabaceae & Whole plant & Ethanol & HIV-reverse transcription & [60] \\
\hline 51 & Phaseolus vulgaris & Fabaceae & Seed & Methanol & HIV-reverse transcription & [64] \\
\hline 52 & Pterocarpus marsupium & Fabaceae & Whole plant & Aqueous & HIV-reverse transcription & [65] \\
\hline 53 & Tripterospermum lanceolatum & Gentianaceae & Whole plant & Methanol & HIV-reverse transcription & [66] \\
\hline 54 & Hypericum hircinum & Hypericaceae & Whole plant & Ethanol & HIV-reverse transcription & [67] \\
\hline 55 & Ajuga decumbens & Lamiaceae & Whole plant & Methanol & HIV-reverse transcription & [68] \\
\hline 56 & Hyssopus officinalis & Lamiaceae & Leaf & Methanol & HIV-reverse transcription & [69] \\
\hline 57 & Ocimum kilimandscharicum & Lamiaceae & Whole plant & Methanol & HIV-reverse transcription & [70] \\
\hline 58 & Ximenia caffra & Olacaceae & Whole plant & Aqueous & HIV-reverse transcription & [71] \\
\hline 59 & Phyllanthus amarus & Phyllanthaceae & Whole plant & Aqueous & HIV-reverse transcription & [72] \\
\hline 60 & Scoparia dulcis & Plantaginaceae & Leaf & Methanol & HIV-reverse transcription & [73] \\
\hline 61 & Canthium coromandelicum & Rubiaceae & Leaf & Methanol & HIV-reverse transcription & [74] \\
\hline 62 & Alisma plantago-aquatica & Alismataceae & Rhizome & Aqueous & HIV-protease & [75] \\
\hline 63 & Toxicodendron acuminatum & Anacardiaceae & Whole & Methanol & HIV-protease & [76] \\
\hline 64 & Xylopia frutescens & Annonaceae & Bark & Aqueous & HIV-protease & [38] \\
\hline 65 & Ammi visnaga & Apiaceae & Fruit & Methanol & HIV-protease & {$[77]$} \\
\hline 66 & Anethum graveolens & Apiaceae & Seed & Methanol & HIV-protease & [76] \\
\hline 67 & Angelica grosseserrata & Apiaceae & Aerial & Aqueous & HIV-protease & [78] \\
\hline 68 & Torilis japonica & Apiaceae & Seed & Methanol & HIV-protease & [78] \\
\hline 69 & Gymnema sylvestre & Apocynaceae & Whole plant & Methanol & HIV-protease & [79] \\
\hline 70 & Garcinia buchneri & Clusiaceae & Steam & Methanol & HIV-protease & [80] \\
\hline 71 & Garcinia kingaensis & Clusiaceae & Steam & Methanol & HIV-protease & [80] \\
\hline
\end{tabular}


The screening of medicinal plants has delivered plenty of secondary metabolites with anti-HIV properties. They include alkaloids, triterpenoids, flavonoids, coumarins, phenolics, tannins, saponins, phospholipids, xanthones, quinones, etc. [81]. There is a large pool of natural compounds with diverse structures, which target different viral targets. Some of them have been found to inhibit HIV integrase and some show RT inhibition (Table 2). The compounds for which we could not establish the mechanism of action will not be included in this review.

Table 2. Bioactive compounds derived from plants with anti-HIV activities.

\begin{tabular}{|c|c|c|c|c|}
\hline No. & Compound & Activity & Dose/IC 50 & Ref. \\
\hline 1 & Ellagic acid & Inhibition of HIV integrase & $90.23 \mu \mathrm{M}$ & [30] \\
\hline 2 & Gallocatechin & Inhibition of HIV integrase & $35.0 \mu \mathrm{M}$ & [31] \\
\hline 3 & Hernandonine & Inhibition of HIV integrase & $16.3 \mu \mathrm{M}$ & [82] \\
\hline 4 & Laurolistine & Inhibition of HIV integrase & $7.7 \mu \mathrm{M}$ & [82] \\
\hline 5 & 7-oxohernangerine & Inhibition of HIV integrase & $18.2 \mu \mathrm{M}$ & [82] \\
\hline 6 & Lindechunine A & Inhibition of HIV integrase & $21.1 \mu \mathrm{M}$ & [82] \\
\hline 7 & Quercitrin & RT inhibition & $60 \mu \mathrm{M}$ & [83] \\
\hline 8 & Gallic acid & Viral infection inhibition & $0.36 \mu \mathrm{g} / \mathrm{mL}$ & [84] \\
\hline 9 & Erythro-7'-methylcarolignan E & Viral infection inhibition & $6.3 \mu \mathrm{M}$ & [83] \\
\hline 10 & Ascalin & RT inhibition & $10 \mu \mathrm{M}$ & {$[85]$} \\
\hline 11 & Justiprocumins A & RT inhibition & $200 \mu \mathrm{g} / \mathrm{mL}$ & [47] \\
\hline 12 & Robustaflavone & RT inhibition & $65 \mu \mathrm{M}$ & [86] \\
\hline 13 & Hinokiflavone & RT inhibition & $65 \mu \mathrm{M}$ & [86] \\
\hline 14 & Agathisflavone & RT inhibition & $119 \mu \mathrm{M}$ & [86] \\
\hline 15 & Morelloflavone & RT inhibition & $100 \mu \mathrm{M}$ & [86] \\
\hline 16 & Michellamines A & RT inhibition & $1 \mu \mathrm{M}$ & [87] \\
\hline 17 & Betulinic acid & RT inhibition & $13 \mu \mathrm{M}$ & [88] \\
\hline 18 & Michellamines A2 & RT inhibition & $29.6 \mu \mathrm{M}$ & [89] \\
\hline 19 & Michellamines A3 & RT inhibition & $15.2 \mu \mathrm{M}$ & [89] \\
\hline 20 & Michellamines A4 & RT inhibition & $35.9 \mu \mathrm{M}$ & [89] \\
\hline 21 & Michellamines B & RT inhibition & $20.4 \mu \mathrm{M}$ & [89] \\
\hline 22 & Lupeol & RT inhibition & $3.8 \mu \mathrm{M}$ & [55] \\
\hline 23 & Lupeol acetate & RT inhibition & $6.4 \mu \mathrm{M}$ & [55] \\
\hline 24 & Chlorogenic acid & RT inhibition & $4.7 \mu \mathrm{M}$ & [55] \\
\hline 25 & Artemisinin & RT inhibition & $100 \mu \mathrm{M}$ & [90] \\
\hline 26 & Luteolin & RT inhibition & $12.8 \mu \mathrm{M}$ & [91] \\
\hline 27 & Gossypetin & RT inhibition & $2 \mu \mathrm{g} / \mathrm{mL}$ & [92] \\
\hline 28 & Xanthohumol & RT inhibition & $0.5 \mu \mathrm{g} / \mathrm{mL}$ & [93] \\
\hline 29 & Kaempferol 3-rhamnosyl-rutinosid & RT inhibition & $0.23 \mu \mathrm{M}$ & [94] \\
\hline 30 & Robustaflavone & RT inhibition & $65 \mu \mathrm{M}$ & [95] \\
\hline 31 & Protostanes & RT inhibition & $5.8 \mu \mathrm{g} / \mathrm{mL}$ & [96] \\
\hline 32 & Morelloflavone & RT inhibition & $86 \mu \mathrm{M}$ & [97] \\
\hline 33 & Anolignan A & RT inhibition & $156 \mu \mathrm{g} / \mathrm{mL}$ & [95] \\
\hline 34 & Cucurbitacins & RT inhibition & $28 \mu \mathrm{M}$ & [98] \\
\hline 35 & Oleanolic acid & RT inhibition & $2 \mu \mathrm{g} / \mathrm{mL}$ & [99] \\
\hline 36 & p-cymene & RT inhibition & $7.6 \mu \mathrm{g} / \mathrm{mL}$ & [99] \\
\hline 37 & Baicalein & RT inhibition & $2 \mu \mathrm{g} / \mathrm{mL}$ & {$[100]$} \\
\hline
\end{tabular}

\section{Herpes Simplex Virus}

The herpes simplex virus (HSV) infection, otherwise known as genital herpes (GH), is the most frequent cause of genital ulceration worldwide. In general, herpes can appear commonly in the mouth and genitals. The primary cause of oral herpes is the HSV-1 type strain, but genital herpes is commonly caused by the HSV-2 type strain [101]. HSV-seronegative persons (vulnerable group) develop a primary infection on their first HSV-1 or HSV-2 exposure. HSV-1 and HSV-2 are normally spread by different routes and affect different areas of the body, however, the signs and symptoms that they cause overlap. The infection happens through primary contact with mucocutaneous surfaces of an infected person, whereas the virus enters the nerve cells to create latency in the sacral dorsal root 
ganglion and lesions at the point of entry. Even though HSV is rarely fatal, most people who have been infected and dormant viruses can reactivate; thus, an extensive of HSV pool is available to spread to vulnerable individuals in the society [102]. The estimated worldwide prevalence of HSV-1 is $67 \%$, whereas HSV-2 is less common, infecting $~ 11 \%$ of the world population with the highest prevalence in Africa [103].

HSV is a member of Herpesviridae, which is a large family of enveloped double-stranded DNA viruses that causes diseases in both human and animals [104]. Even though Herpesviridae viruses vary in tissue tropism and host interaction mechanisms, they have a much-conserved tool by which they replicate their DNA in infection. Among the members of this family, HSV has been much exploited to study its mechanism of replication. It is well understood that other viruses of this family follow similar replication pathways, but they differ in the pace of activity [105]. Initially, the host cell attachment happens with the HSV virus. This attachment occurs at the heparan sulfate moieties of cellular proteoglycans with the glycoprotein present in the virus envelope, where they bind with the secondary cellular receptors. After the attachment, the viral envelope is released into the cytosol. This will facilitate the movement of capsid toward the nuclear pore, where the viral DNA will be released via the capsid portal. Once in the nucleus, viral DNA transcription leads to mRNA by cellular RNA polymerase II. This viral gene expression is tightly regulated, which is comprised of three kinetic expressions such as early, intermittent, and late mRNA formation. All mRNA transcripts are translated into proteins and travel into the nucleus from the cytoplasm. Capsid proteins assemble in the nucleus to form empty capsids. Then, the newly formed capsids are released from the nucleus to the cytoplasm, where they form its final vesicles $[106,107]$. Then, the formed virus accumulates in the endoplasmic reticulum and is subsequently released by exocytosis (Figure 2).

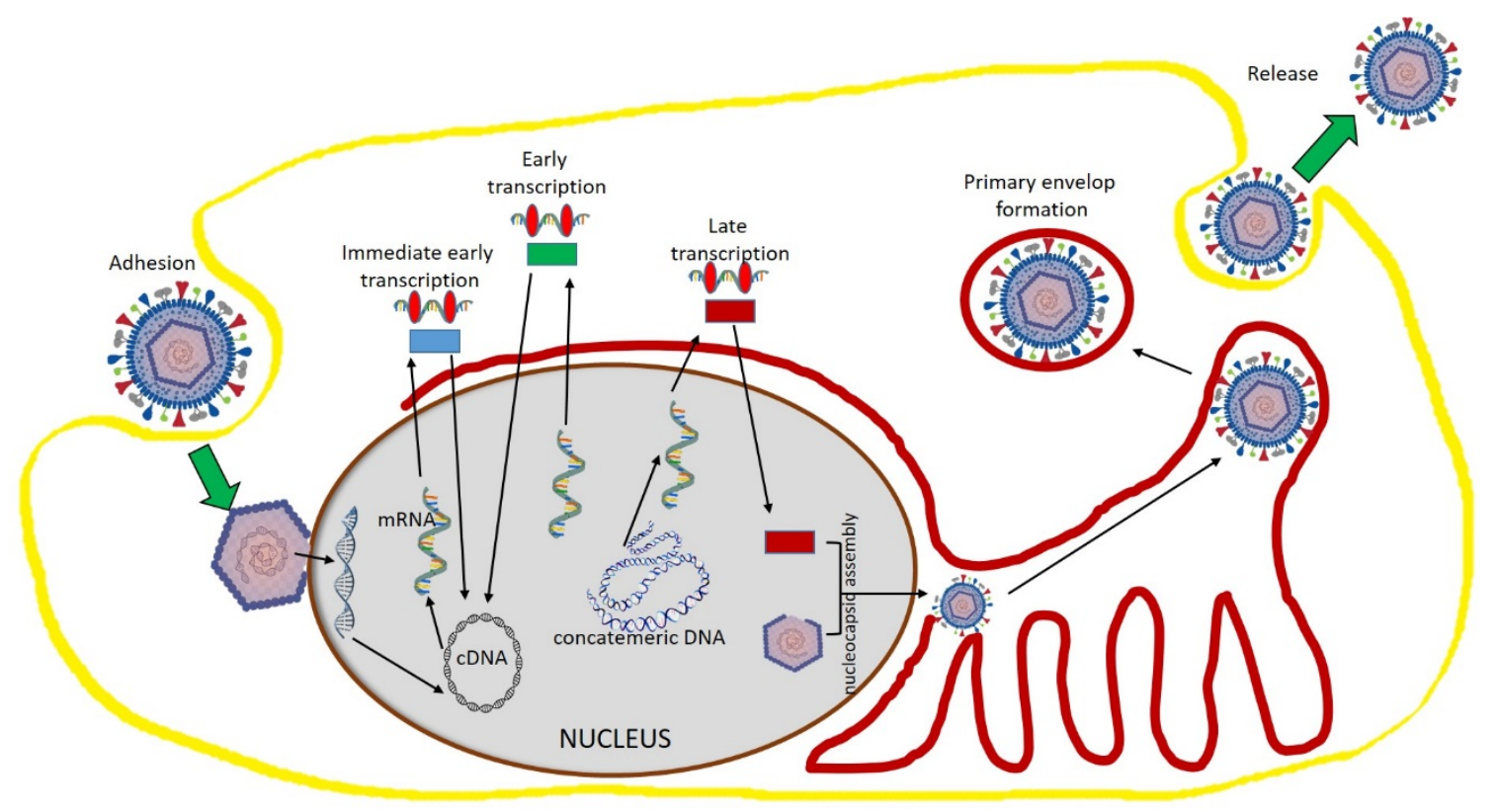

Figure 2. Herpes simplex virus structure and replication mechanism. The HSV structure in this figure has been modified from the source https://pnghut.com.

There is no ultimate cure for HSV, but the current strategies are mainly focused on symptomatic relief. Both innate and adaptive immune systems can control HSV infections. In fact, the nature of HSV infection is dependent upon how the virus bypasses the host innate immune system. In the current system of practice, antiviral drugs are classified as virucidal, immunomodulators, and chemotherapeutic agents [108]. There is a starting treatment for HSV with acyclovir, valacyclovir, or famciclovir for 7-10 days for primary HSV infections [109]. After that, the treatment will be started only when the recurrence of HSV occurs, and the treatment will be episodic for five 
days to prevent the symptoms and prevent recurrence [110]. These drugs act via a mechanism of inhibition of DNA polymerase. Even though these drugs are in practice, they can fail to meet the treatment expectation via either unwanted drug side effects or drug resistance to nucleoside analogues via mutation. Therefore, clinicians and microbiologists are always looking for a better alternative.

The natural products always served as a trustable source for new compounds with antiviral properties. Many studies have been carried out since 1995 to isolate bioactive antiviral compounds from plants and functional foods. Accordingly, a large number of plant-derived anti-HSV drugs have been described in several studies. A list of plant species with inhibition studies is summarized in Table 3. 
Table 3. Review of the plants that show anti-herpes simplex virus activities with their prospective family, part, type of extract, and inhibition target.

\begin{tabular}{|c|c|c|c|c|c|c|}
\hline No. & Plant & Family & Part & Extract & Mode of Action/Virus & Ref. \\
\hline 1 & Peganum harmala & Nitrariaceae & Seed & Methanol & Virucidal action/HSV2 & [111] \\
\hline 2 & Pistacia vera & Anacardiaceae & Seed & Methanol & Viral DNA synthesis inhibition/HSV1 & {$[112$} \\
\hline 3 & Rhus aromatica & Anacardiaceae & Root & Aqueous & Inhibit the virus penetration/HSV1 & {$[113$} \\
\hline 4 & Quercus brantii & Cynipidae & Fruit & Chloroform & Inhibit virus entry/HSV1 & {$[114]$} \\
\hline 5 & Tanacetum parthenium & Asteraceae & Arial & Aqueous & Virus replication imbibition/HSV1 & {$[115$} \\
\hline 6 & Centella asiatica & Umbelliferae & Aerial & Aqueous & Inhibition of viral replication/HSV2 & {$[116$} \\
\hline 7 & Pistacia lentiscus & Anacardiaceae & Stem & Methanol & Virus absorption imbibition/HSV2 & [111] \\
\hline 8 & Mangifera indica & Anacardiaceae & Leaves & Aqueous & Inhibition of viral replication/HSV2 & [116 \\
\hline 9 & Eucalyptus denticulata & Myrtaceae & Aerial & Acetone & Inhibit virus entry/HSV1 & [117] \\
\hline 10 & Aglaia odorata & Meliaceae & Leaf & Ethanol & Inhibition of viral replication/HSV2 & [118 \\
\hline 11 & Euphorbia coopire & Euphorbiaceae & Flowers & Chloroform/methylene chloride & Inhibition of viral replication/HSV1 & [119] \\
\hline 12 & Rhus aromatica & Anacardiaceae & Bark & Aqueous & Inhibit virus entry/HSV2 & [113] \\
\hline 13 & Anacardium occidentale & Anacardiaceae & Leaf & Aqueous & Inhibition of viral replication/HSV2 & {$[120]$} \\
\hline 14 & Phoradendron crassifolium & Loranthaceae & Leaf & Ethanol & Inhibition of viral replication/HSV2 & {$[120]$} \\
\hline 15 & Morus alba & Moraceae & Leaf & Aqueous methanol & Inhibition of viral replication/HSV1 & [119] \\
\hline 16 & Aloe vera & Liliaceae & Leaf & Gel & Replication inhibition/HSV1 & [121] \\
\hline 17 & Annona muricata & Annonaceae & Stembark & Petroleum ether & Inhibition of viral replication/HSV2 & {$[122]$} \\
\hline 18 & Petunia nyctaginiflora & Solanaceae & Stembark & Petroleum ether & Inhibition of viral replication/HSV2 & {$[122]$} \\
\hline 19 & Cuphea carthagenensis & Lythraceae & Ariel & Ethanol & Inhibition of viral replication/HSV1 & [123] \\
\hline 20 & Graptopetalum paraguayense & Crassulaceae & Leaf & Methanol/water & Inhibition of viral replication/HSV1 & {$[124]$} \\
\hline 21 & Prunus dulcis & Rosaceae & Almond skin & Methanol/Hcl & Block virus entry & {$[125]$} \\
\hline 22 & Equisetum giganteum & Equisetaceae & Root and stem & Ethanol/water & Inhibition of viral cell attachment and entry/HSV2 & {$[126]$} \\
\hline 23 & Schinus terebinthifolia & Anacardiaceae & Bark & Ethanol/water & Inhibition of viral attachment and penetration/HSV1 & {$[127$} \\
\hline 24 & Nepeta nuda & Lamiaceae & Aerial & Aqueous & Inhibition of viral absorption and replication/HSV1 & {$[128]$} \\
\hline 25 & Cornus canadensis & Cornaceae & Leaf & Aqueous & Virus absorption inhibition/HSV1 & {$[129]$} \\
\hline 26 & Strychnos pseudoquina & Loganiaceae & Stem & Ethyl acetate & $\begin{array}{l}\text { Interference with various } \\
\text { steps of virus cycle/HSV1 }\end{array}$ & {$[130]$} \\
\hline 27 & Tillandsia usneoides & Bromeliaceae & Fruits & Ethanol & Inhibition of viral replication/HSV1 & [123] \\
\hline 28 & Copaifera reticulate & Fabaceae & Leaf & Ethanol/water & Inhibition of viral cell attachment and entry/HSV2 & {$[126]$} \\
\hline 29 & Spondias mombin & Anacardiaceae & Leaf & Methanol & Inhibition of viral cell attachment/HSV1 & [131] \\
\hline 30 & Solanum melongena & Solanaceae & Peel & Ethanol & $\begin{array}{l}\text { Reduction of viral protein } \\
\text { Expression/HSV1 }\end{array}$ & {$[132$} \\
\hline 31 & Ixeris Sonchifolia & Compositae & Whole plant & Methanol & Inhibition of viral replication/HSV1 & {$[133$} \\
\hline 32 & Eurycoma longifolia & Simaroubaceae & Stem & Methanol & Inhibition of viral replication/HSV1 & [134] \\
\hline 33 & Garcinia mangostana & Guttiferae & Leaf & Methanol & Inhibition of viral replication/HSV1 & {$[134]$} \\
\hline 34 & Peganum harmala & Nitrariaceae & Seed & Methanol & Block virus entry/HSV2 & [135] \\
\hline 35 & Erica multiflora & Ericaceae & Ariel & Methanol & Inhibition of viral replication/HSV1 & [136] \\
\hline 36 & Toona sureni & Meliaceae & Leaf & Methanol & Inhibition of viral replication/HSV1 & [134] \\
\hline
\end{tabular}


Table 3. Cont.

\begin{tabular}{|c|c|c|c|c|c|c|}
\hline No. & Plant & Family & Part & Extract & Mode of Action/Virus & Ref. \\
\hline 37 & Eucalyptus caesia & Myrtaceae & Aerial & Hydro-distillation & Virucidal activity/HSV1 & [137] \\
\hline 38 & Vachellia nilotica & Fabaceae & Bark & Methanol & Block virus attachment/HSV2 & [138] \\
\hline 39 & Stephania cepharantha & Menispermaceae & Root & Methanol & Virucidal effect/HSV1 & [139] \\
\hline 40 & Zygophyllum album & Zygophyllaceae & Whole plant & Acetone & Virucidal effect/HSV1 & [136] \\
\hline 41 & Ficus religiosa & Moraceae & Bark & Methanol & Virucidal effect/HSV1 & [140] \\
\hline 42 & Eucalyptus alba & Myrtaceae & Fruit & Aqueous & Virucidal effect/HSV1 & [134] \\
\hline 43 & Swertia chirata & Renunculaceae & Leaf & Aqueous & Virucidal effect/HSV1 & [141] \\
\hline 44 & Scoparia dulcis & Plantaginaceae & Leaf & Methanol & Inhibit the viral replication/HSV1 & [142] \\
\hline 45 & Pedilanthus tithymaloides & Euphorbiaceae & Leaves & Methanol & inhibition of viral replication/HSV2 & [143] \\
\hline 46 & Melaleuca leucadendron & Myrtaceae & Fruit & Aqueous & Virucidal effect/HSV1 & [134] \\
\hline 47 & Andrographis paniculata & Acanthaceae & Leaf & Ethanol & Virucidal effect/HSV1 & [144] \\
\hline 48 & Artemisia kermanensis & Asteraceae & Aerial & Hydro-distillation & Virucidal activity/HSV1 & [137] \\
\hline 49 & Vigna radiata & Fabaceae & Spout & Methanol & Virucidal activity/HSV1 & [145] \\
\hline 50 & Schleichera oleosa & Sapindaceae & Fruit & Aqueous & Virucidal activity/HSV1 & [134] \\
\hline 51 & Quercus persica & Fagaceae & Fruit & Hydro alcoholic & Viral attachment inhibition/HSV1 & [146] \\
\hline 52 & Pongamia pinnata & Papillionaceae & Seed & Aqueous & Virucidal activity/HSV1 & [147] \\
\hline 53 & Pterocarya stenoptera & Juylandaceae & Bark & Methanol & Viral attachment and penetration inhibition/HSV2 & [148] \\
\hline 54 & Avicennia marina & Avicenniaceae & Leaf & Methanol & Viral replication inhibition/HSV1 & [149] \\
\hline 55 & Nephelium lappaceum & Sapindaceae & Pericarp & Water/methanol & Virucidal activity/HSV1 & [134] \\
\hline 56 & Zataria multiflora & Labiatae & Aerial & Hydro-distillation & Virucidal activity/HSV1 & [137] \\
\hline 57 & Ocimum sanctum & Lamiaceae & Aerial & Methanol & Viral infection inhibition/HSV1 & [150] \\
\hline 58 & Artocarpus lakoocha & Moraceae & Wood & Methanol & Viral infection inhibition/HSV1 & [106] \\
\hline 59 & Scaevola gaudichaudiana & Asteraceae & Aerial & Dichloromethane & Viral absorption inhibition/HSV1 & [151] \\
\hline 60 & Rosmarinus officinalis & Lamiaceae & Aerial & Hydro-distillation & Virucidal activity/HSV1 & [137] \\
\hline 61 & Limonium sinense & Plumbaginaceae & Root & Ethanol & Virucidal activity/HSV1 & [152] \\
\hline 62 & Prunella vulgaris & Lamiaceae & Fruit spikes & Aqueous & Block HSV-1 binding & [153] \\
\hline 63 & Heterophyllaea pustulata & Rubiaceae & Fruit & Dried powder & Viral absorption inhibition/HSV1 & [154] \\
\hline 64 & Filicium decipiens & Sapindaceae & Stem bark & Water/methanol & Virucidal activity/HSV1 & [134] \\
\hline 65 & Punica granatum & Punicaceae & Pericarp & Water/methanol & Virucidal activity/HSV1 & [134] \\
\hline 66 & Satureja hotensis & Lamiaceae & Aerial & Hydrodistillation & Virucidal activity/HSV1 & [137] \\
\hline
\end{tabular}


Many herbal compounds have been investigated in the past for their effectiveness against HSV. The purification of new lead compounds from the plants and evaluating their targets and mechanism of action in HSV is also equally important. Many secondary metabolites have been proven to have anti-HSV effects such as lignans, tannins, saponins, terpenes, alkaloids, quinones, and glucosides [155-158]. In Table 4, we have mentioned the compounds that exhibited viral inhibition with inhibitory activity at the early phase and late phase of replication and HSV viral inhibition with $\mathrm{IC}_{50}$ dose. 
Table 4. Bioactive compounds derived from plants with anti-HSV activities.

\begin{tabular}{|c|c|c|c|c|}
\hline No. & Compound & Activity & Dose/IC 50 & Ref. \\
\hline 1 & $4 E$-jatrogrossidentadion & Viral inhibition/HSV 1 & $2.05 \mu \mathrm{g} / \mathrm{mL}$ & [159] \\
\hline 2 & 7-galloyl catechin & Viral inhibition/HSV 1 & $43.2 \mu \mathrm{g} / \mathrm{mL}$ & [119] \\
\hline 3 & Gallic acid & Viral inhibition/HSV 1 & $49.8 \mu \mathrm{g} / \mathrm{mL}$ & [119] \\
\hline 4 & Kaempferol 3-O- $\beta$-(6"-O-galloyl)-glucopyranoside & Viral inhibition/HSV 1 & $124.1 \mu \mathrm{g} / \mathrm{mL}$ & [119] \\
\hline 5 & Quercetin 3-O- $\beta$-(6"-O-galloyl)-glucopyranoside & Viral inhibition/HSV 1 & $175.6 \mu \mathrm{g} / \mathrm{mL}$ & [119] \\
\hline 6 & Curcumin & Viral inhibition/HSV 1 & $49.8 \mu \mathrm{g} / \mathrm{mL}$ & [119] \\
\hline 7 & Quercetin & Viral inhibition/HSV 1 & $78.1 \mu \mathrm{g} / \mathrm{mL}$ & [119] \\
\hline 8 & Kaempferol & Viral inhibition/HSV 1 & $76.1 \mu \mathrm{g} / \mathrm{mL}$ & [119] \\
\hline 9 & 3,4-Dehydrocycleanine & Viral inhibition/HSV 1 & $43.2 \mu \mathrm{g} / \mathrm{mL}$ & [139] \\
\hline 10 & $(-)$-Cycleanine & Viral inhibition/HSV 1 & $26.3 \mu \mathrm{g} / \mathrm{mL}$ & [139] \\
\hline 11 & (-)-Norcycleanine & Viral inhibition/HSV 1 & $18.1 \mu \mathrm{g} / \mathrm{mL}$ & [139] \\
\hline 12 & 2-Norcepharanoline & Viral inhibition/HSV 1 & $26.3 \mu \mathrm{g} / \mathrm{mL}$ & [139] \\
\hline 13 & Obaberine & Viral inhibition/HSV 1 & $14.8 \mu \mathrm{g} / \mathrm{mL}$ & [139] \\
\hline 14 & Homoaromoline & Viral inhibition/HSV 1 & $15.1 \mu \mathrm{g} / \mathrm{mL}$ & [139] \\
\hline 15 & Aromoline & Viral inhibition/HSV 1 & $20.4 \mu \mathrm{g} / \mathrm{mL}$ & [139] \\
\hline 16 & Isotetrandrine & Viral inhibition/HSV 1 & $17.4 \mu \mathrm{g} / \mathrm{mL}$ & [139] \\
\hline 17 & Berbamine & Viral inhibition/HSV 1 & $17.4 \mu \mathrm{g} / \mathrm{mL}$ & [139] \\
\hline 18 & Thalrugosine & Viral inhibition/HSV 1 & $16.8 \mu \mathrm{g} / \mathrm{mL}$ & [139] \\
\hline 19 & Obamegine & Viral inhibition/HSV 1 & $23.5 \mu \mathrm{g} / \mathrm{mL}$ & [139] \\
\hline 20 & 2-Norberbamine & Viral inhibition/HSV 1 & $16.8 \mu \mathrm{g} / \mathrm{mL}$ & [139] \\
\hline 21 & 3',4'-Dihydrostephasubine & Viral inhibition/HSV 1 & $27.4 \mu \mathrm{g} / \mathrm{mL}$ & [139] \\
\hline 22 & Palmatine & Viral inhibition/HSV 1 & $34.0 \mu \mathrm{g} / \mathrm{mL}$ & [139] \\
\hline 23 & Cephakicine & Viral inhibition/HSV 1 & $44.5 \mu \mathrm{g} / \mathrm{mL}$ & [139] \\
\hline 24 & $\mathrm{~N}$-Methylcrotsparine & Viral inhibition/HSV 1 & $8.3 \mu \mathrm{g} / \mathrm{mL}$ & [139] \\
\hline 25 & Andrographolide & Viral inhibition/HSV 1 & $8.28 \mu \mathrm{g} / \mathrm{mL}$ & [144] \\
\hline 26 & Neoandrographolide & Viral inhibition/HSV 1 & $7.97 \mu \mathrm{g} / \mathrm{mL}$ & [144] \\
\hline 27 & 14-Deoxy-11,12-didehydroandrographolide & Viral inhibition/HSV 1 & $11.1 \mu \mathrm{g} / \mathrm{mL}$ & [144] \\
\hline 28 & Oxyresveratrol & Inhibitory activity at the early phase and late phase of replication/HSV1 & $24 \mu \mathrm{g} / \mathrm{mL}$ & [106] \\
\hline 29 & Samarangenin B & Inhibition of viral replication/HSV1 & $11.4 \mu \mathrm{g} / \mathrm{mL}$ & [152] \\
\hline 30 & (-)-epigallocatechin 3-O-gallate & Viral inhibition/HSV 1 & $38.6 \mu \mathrm{g} / \mathrm{mL}$ & [152] \\
\hline 31 & Pterocarnin A & Viral attachment inhibition/HSV 1 & $5.4 \mu \mathrm{M}$ & [148] \\
\hline 32 & Scopadulcic acid B & Viral attachment inhibition/HSV 1 & $0.012 \mu \mathrm{M}$ & [142] \\
\hline
\end{tabular}




\section{Influenza Virus}

Pandemics are the mainly remarkable appearances of the influenza virus [160]. Three pandemics happened in the previous century: the H1N1 pandemic (1918), the H2N2 pandemic (1957), and the H3N2 pandemic (1968) [161,162]. Influenza is observed nationally and internationally through a multiparty system of surveillance systems distributed worldwide that eventually feeds into the WHO global influenza program $[163,164]$. The annual incidence is 3.5 million, with more than 250,000 deaths [165]. Alpha-influenzavirus is the primary cause of all the pandemics [166,167]. Various waves of beta-influenzavirus flu were observed in local settings around the world [168].

Influenza virus belongs to Orthomyxoviridae family (RNA viruses), which includes seven genera (Alpha, Beta, Delta, Gamma, Isavirus, Quaranjavirus, and Thogotovirus) [169,170]. Alpha, Beta, Delta, and Gamma caused mammalian flu. There are 18 various hemagglutinin (HA) subtypes and 11 various neuraminidase (NA) subtypes [171,172]. Subtypes are named by combining the $H$ and $\mathrm{N}$ numbers-e.g., $\mathrm{A}(\mathrm{H} 1 \mathrm{~N} 1), \mathrm{A}(\mathrm{H} 3 \mathrm{~N} 2)$. On the other hand, influenza $\mathrm{B}$ viruses are classified into two lineages: B/Yamagata and B/Victoria $[173,174]$. This genetic pattern imitates the altered nature of the antigenic properties of these viruses, and their following outbreak depends upon various factors $[174,175]$. Influenza B virus was supposed to have a weaker rate of antigenic progression than A and to cause milder sickness than A in the past $[176,177]$.

Influenza virus mainly targets the columnar epithelial cells in the respiratory tract [178]. Firstly, the hemagglutinin (HA) present in the receptor binding site of virus attached to galactose bound sialic acid on the surface of the host. This receptor binding is the determining factor for turning part of an organism in a particular direction of infection in response to a virus stimulus. To achieve this receptor binding, the virus undergoes tremendous efforts to bypass host immune responses, mucociliary clearance, and genetic diversification of the host receptor. Then, after the binding, viron enters the host cell by an endocytosis mechanism with the protease cleavage of hemagglutinin. Then, the viron produces a vacuole membrane, which releases the viral RNA and proteins into the cytosol. These proteins and RNA form a complex (vRNA/RdRP), which reaches the nucleus $[179,180]$. Then, the viral RNA is translated into newly synthesized proteins, which are secreted via the Golgi apparatus to the nucleus to bind viral RNA to form a viral particle. Later, the RNA particle and viral proteins accumulate to form a new viron and buds off from the cell membrane (Figure 3).

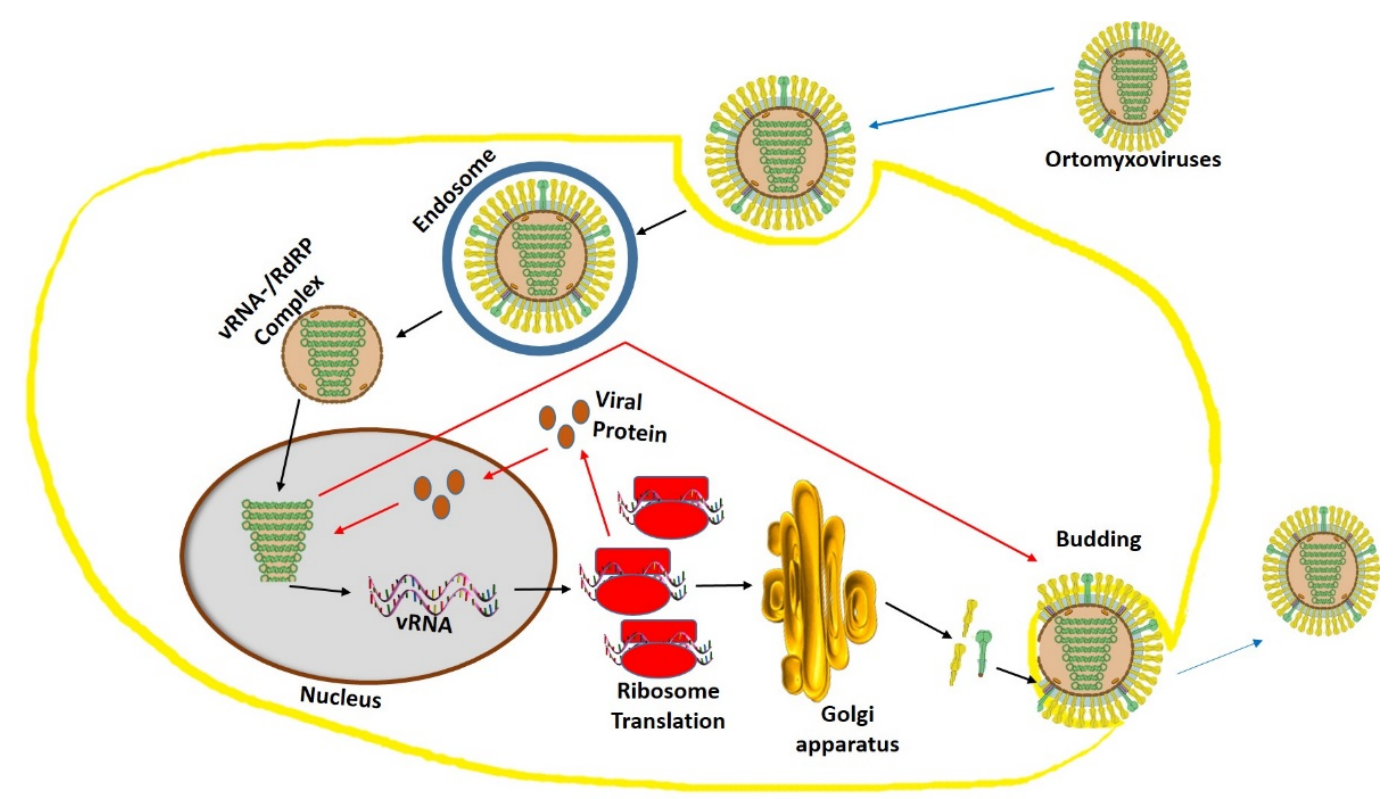

Figure 3. Orthomyxovirus structure and replication mechanism. The Orthomyxovirus structure in this figure has been modified from the source https://viralzone.expasy.org/. 
In the contingency of a flu pandemic with a new strain, antiviral drugs symbolize the primary line of defense [181,182]. Research on the development of anti-influenza medications was started a long time ago $[183,184]$. This approach was based on the two mechanisms that induce viral replication in host immune reactions $[185,186]$. Viral replication has various cellular targets starting from the release of the new viruses from the host cells. Many drugs were scientifically proven to inhibit M2 Ion Channel and Neuraminidase on the virus itself $[187,188]$, while other drugs work on some cell pathways evolving intracellular defense mechanisms [189]. This research on the development of anti-influenza medications also includes identifying traditional medicinal plant extracts and active compounds with anti-influenza activity [190]. These folk drugs were developed as an alternative to synthetic drugs. The exploration of plant-based antivirals against the influenza virus is hopeful, as several plants have been shown to have anti-influenza action. Therefore, the current review paper summarizes the previous findings and efforts of some studies on discovering anti-influenza medications from medicinal plants. A list of plant species with inhibition studies is summarized in Table 5. 
Table 5. Review of the plants that have shown anti-flu virus activities with their prospective family, part, type of extract, and inhibition target.

\begin{tabular}{|c|c|c|c|c|c|c|}
\hline No. & Plant & Family & Part & Extract & Inhibition Target & Ref. \\
\hline 1 & Cistus incanus & Cistaceae & Whole plant & Polyphenol-rich plant extract & MDCK cell-based assay & {$[191]$} \\
\hline 2 & Thuja orientalis & Cupressaceae & Leaves & Methanol & $\begin{array}{l}\text { Blockage of attachment to the host cells } \\
\text { and inhibition of replication }\end{array}$ & {$[192]$} \\
\hline 3 & Pimpeniella anisum & Apiaceae & Seeds & Aqueous & Direct effect on replication & {$[193]$} \\
\hline 4 & Aloe sinana & Xanthorrhoeaceae & Root and leaf latex & Methanol & $\begin{array}{l}\text { Induced CPE and increased the cell } \\
\text { viability of Vero cells }\end{array}$ & {$[194]$} \\
\hline 5 & Punica granatum L. & Lythraceae & Peel & Ethanol & Inhibit influenza A virus replication & {$[195]$} \\
\hline 6 & Geranium thunbergii & Geranii Herba & Dried aerial part & Ethanol & Neuraminidase (NA) inhibitors & {$[196]$} \\
\hline 7 & Mussaenda elmeri & Rubiaceae & Whole plant & $\begin{array}{l}\text { Dichloromethane and methanol } \\
\text { in a } 1 / 1(v / v) \text { ratio }\end{array}$ & Inhibition of hemagglutination & {$[197]$} \\
\hline 8 & Trigonopleura malayana & Euphorbiaceae & Leaves & $\begin{array}{l}\text { Dichloromethane and methanol } \\
\text { in a } 1 / 1(v / v) \text { ratio }\end{array}$ & Inhibition of hemagglutination & [197] \\
\hline 9 & Mussaenda elmeri & Rubiaceae & Whole plant & $\begin{array}{l}\text { Dichloromethane and methanol } \\
\text { in a } 1 / 1(v / v) \text { ratio }\end{array}$ & Inhibition of hemagglutination & {$[197]$} \\
\hline 10 & Santiria apiculata & Burseraceae & Whole plant & $\begin{array}{l}\text { Dichloromethane and methanol } \\
\text { in a } 1 / 1(v / v) \text { ratio }\end{array}$ & Inhibition of hemagglutination & [197] \\
\hline 11 & Anisophyllea disticha & Anisophylleaceae & Stems & $\begin{array}{l}\text { Dichloromethane and methanol } \\
\text { in a } 1 / 1(v / v) \text { ratio }\end{array}$ & Inhibition of hemagglutination & {$[197]$} \\
\hline 12 & Trivalvaria macrophylla & Annonaceae & Roots & $\begin{array}{l}\text { Dichloromethane and methanol } \\
\text { in a } 1 / 1(v / v) \text { ratio }\end{array}$ & Inhibition of hemagglutination & {$[197]$} \\
\hline 13 & Baccaurea angulata & Euphorbiaceae & Stems & $\begin{array}{l}\text { Dichloromethane and methanol } \\
\text { in a } 1 / 1(v / v) \text { ratio }\end{array}$ & Inhibition of hemagglutination & [197] \\
\hline 14 & Tetracera macrophylla & Dilleniaceae & Leaves & $\begin{array}{l}\text { Dichloromethane and methanol } \\
\text { in a } 1 / 1(v / v) \text { ratio }\end{array}$ & Inhibition of hemagglutination & {$[197]$} \\
\hline 15 & Calophyllum lanigerum & Clusiaceae & Whole plant & $\begin{array}{l}\text { Dichloromethane and methanol } \\
\text { in a } 1 / 1(v / v) \text { ratio }\end{array}$ & Inhibition of hemagglutination & {$[197]$} \\
\hline 16 & Calophyllum lanigerum & Clusiaceae & Stems & $\begin{array}{l}\text { Dichloromethane and methanol } \\
\text { in a } 1 / 1(v / v) \text { ratio }\end{array}$ & Inhibition of hemagglutination & {$[197]$} \\
\hline 17 & Albizia corniculata & Fabaceae & Stems & $\begin{array}{l}\text { Dichloromethane and methanol } \\
\text { in a } 1 / 1(v / v) \text { ratio }\end{array}$ & Inhibition of hemagglutination & {$[197]$} \\
\hline 18 & Mussaenda elmeri & Rubiaceae & Whole plant & $\begin{array}{l}\text { Dichloromethane and methanol } \\
\text { in a } 1 / 1(v / v) \text { ratio }\end{array}$ & Inhibition of hemagglutination & {$[197]$} \\
\hline 19 & Polygonum chinense & Polygonaceae & Whole plant & Methanol & $\begin{array}{l}\text { Inhibited viral replication viral } \\
\text { neuraminidase }\end{array}$ & {$[198]$} \\
\hline 20 & Bletilla striata & Orchidaceae & Rhizomes & Ethanol & Viability assay & {$[199]$} \\
\hline
\end{tabular}


Table 5. Cont.

\begin{tabular}{|c|c|c|c|c|c|c|}
\hline No. & Plant & Family & Part & Extract & Inhibition Target & Ref. \\
\hline 21 & Jatropha multifida Linn & Euphorbiaceae & Stems & $70 \%$ aqueous ethanol & Virus-infected MDCK cells-based assay & [200] \\
\hline 22 & Dandelion & Asteraceae & Whole plant & Aqueous & $\begin{array}{l}\text { Inhibit polymerase activity and reduce } \\
\text { virus nucleoprotein (NP) RNA level. }\end{array}$ & [201] \\
\hline 23 & Radix Paeoniae Alba & Paeoniaceae & Roots & Aqueous & Inhibit the replication & [202] \\
\hline 24 & Balanites aegyptiaca, & Zygophyllaceae & Leaves & Aqueous or $70 \%$ methanol & $\begin{array}{l}\text { Inhibited the virus-induced } \\
\text { hemagglutination of chicken RBCs }\end{array}$ & [203] \\
\hline 25 & Cordia africana, & Boraginaceae & Bark & Aqueous or $70 \%$ methanol & $\begin{array}{l}\text { Inhibited the virus-induced } \\
\text { hemagglutination of chicken RBCs }\end{array}$ & [203] \\
\hline 26 & Aristolochia bracteolata & Aristolochiaceae & Whole plant & Aqueous or $70 \%$ methanol & $\begin{array}{l}\text { Inhibited the virus-induced } \\
\text { hemagglutination of chicken RBCs }\end{array}$ & [203] \\
\hline 27 & Boscia senegalensis & Capparaceae & Leaves & Aqueous or $70 \%$ methanol & $\begin{array}{l}\text { Inhibited the virus-induced } \\
\text { hemagglutination of chicken RBCs }\end{array}$ & [203] \\
\hline 28 & Leptadenia arborea & Apocynaceae & Roots & Aqueous or $70 \%$ methanol & $\begin{array}{l}\text { Inhibited the virus-induced } \\
\text { hemagglutination of chicken RBCs }\end{array}$ & [203] \\
\hline 29 & Punica granatumL. & Lythraceae & Peel & Ethyl alcohol extract & $\begin{array}{c}\text { Inhibition of viral adsorption and viral } \\
\text { RNA transcription }\end{array}$ & [204] \\
\hline 30 & Caesalpinia decapetala & Fabaceae & Leaves & $75 \%$ aqueous ethanol & Inhibit replication & [205] \\
\hline
\end{tabular}


Among viral infections, the viruses of the influenza viral infection have the ability to mutate their genome and become resistant to drugs [206]. Thus, the discovery of phytochemicals against the influenza virus is more challenging compared to other viruses. Among the phytochemicals, alkaloids have shown superior activity against flu virus. It is believed that the alkaloids have the ability to kill virus by the induction of interferon of the immune system [207]. Some alkaloids can increase the phagocytosis by macrophages activity, whereas some can inhibit viral protein synthesis [208]. Besides, the inhibition of influenza by lignans [209] and terpenes [210] was well documented. In Table 6, we have mentioned the compounds that exhibited inhibitory activity on viral inhibition with an $\mathrm{IC}_{50}$ dose.

Table 6. Bioactive compounds derived from plants with anti-flu activities.

\begin{tabular}{|c|c|c|c|c|}
\hline No. & Compound & Activity & Dose/IC 50 & Ref. \\
\hline 1 & Pentagalloylglucose & Inhibited the virus-induced hemagglutination of chicken RBCs & $11.3 \mu \mathrm{g} / \mathrm{mL}$ & [211] \\
\hline 2 & Quercetin & Inhibit the entry of the H5N1 virus & $7.75 \mu \mathrm{g} / \mathrm{mL}$ & [212] \\
\hline 3 & Apigenin & Inhibited viral replication viral neuraminidase & $21.54 \mu \mathrm{M}$ & [213] \\
\hline 4 & Baicalein & Inhibited H5N1 viral replication viral neuraminidase & $18.79 \mu \mathrm{M}$ & [213] \\
\hline 5 & Biochanin A & Inhibited H5N1 viral replication viral neuraminidase & $8.92 \mu \mathrm{M}$ & [213] \\
\hline 6 & Hispidulin & Inhibition against H1N1 neuraminidase & $11.18 \mu \mathrm{M}$ & [214] \\
\hline 7 & Nepetin & Inhibition against $\mathrm{H} 1 \mathrm{~N} 1$ neuraminidase & $12.54 \mu \mathrm{M}$ & [214] \\
\hline 8 & Rosmarinic acid methyl ester & Inhibition against $\mathrm{H} 1 \mathrm{~N} 1$ neuraminidase & $15.47 \mu \mathrm{M}$ & [214] \\
\hline 9 & Luteolin & Inhibition against H1N1 neuraminidase & $19.83 \mu \mathrm{M}$ & [214] \\
\hline 10 & Homonojirimycin & Inhibition against H1N1 neuraminidase & $10.4 \mu \mathrm{g} / \mathrm{mL}$ & [215] \\
\hline 11 & Dendrobine & Inhibited early steps in the H1N1 viral replication cycle & $3.39 \mu \mathrm{g} / \mathrm{mL}$ & [216] \\
\hline
\end{tabular}

\section{Hepatitis C Virus}

Hepatitis $\mathrm{C}$ virus (HCV) infection is considered as a significant public health problem. It has infected around 180 million people worldwide [217]. In developed nations, the transmission is thought to be through sharing and the unsafe use of needles among drug users. In the meantime, in the other parts of the world, unsafe blood transfusion and unhealthy injection practices contribute to the development of HCV infection [218]. At present, no vaccine against HCV is available, and the presence of a high diversity of viral isolates will possibly make it very hard to develop a vaccine. Over the last five years, direct-acting antiviral agents (DAAs) have revolutionized the treatment of HCV infection with their specific mechanism of action [219]. DAAs were introduced in 2014, provided effective interferon-free therapy combinations for all HCV genotype, and have very few safety considerations. Serious adverse events are rare, but drug-drug interactions are considered a major issue regarding the choice of DAA regimen, which needs drug-drug interaction assessment before starting therapy [220].

Hepatitis $C$ virus belongs to the Hepacivirus genus of the Flaviviridae family. It is a small enveloped virus with single-stranded genomic RNA with two embedded viral glycoproteins [221]. In the perisinusoidal space (between hepatocyte and a sinusoid), the lipo-viral particle is attached to the basolateral surface of the hepatocyte by virtue of a variety of receptors such as proteoglycans, LDL receptor, CD81, and claudin 1. After the endocytosis, the M2 proteins allow a pH-dependent fusion with the lysosome and the protons to move through the viral envelope, causing the uncoating and release of the viral RNA. Then, the viral replication proteins recruit membranes from the Endoplasmic Reticulum (ER) to form the closely ER-associated "Membranous web", which is the site of viral replication. Afterward, the viral particles will remain in the nucleus or move to the cytosol, where they are translated into viral proteins via the Golgi apparatus. In addition, the viral proteins sometimes are brought back into the nucleus, where they bind with viral RNA and later form new viral genome particles $[222,223]$. The new virion buds off from the cell in a phospholipid sphere and is released from the cell (Figure 4). 


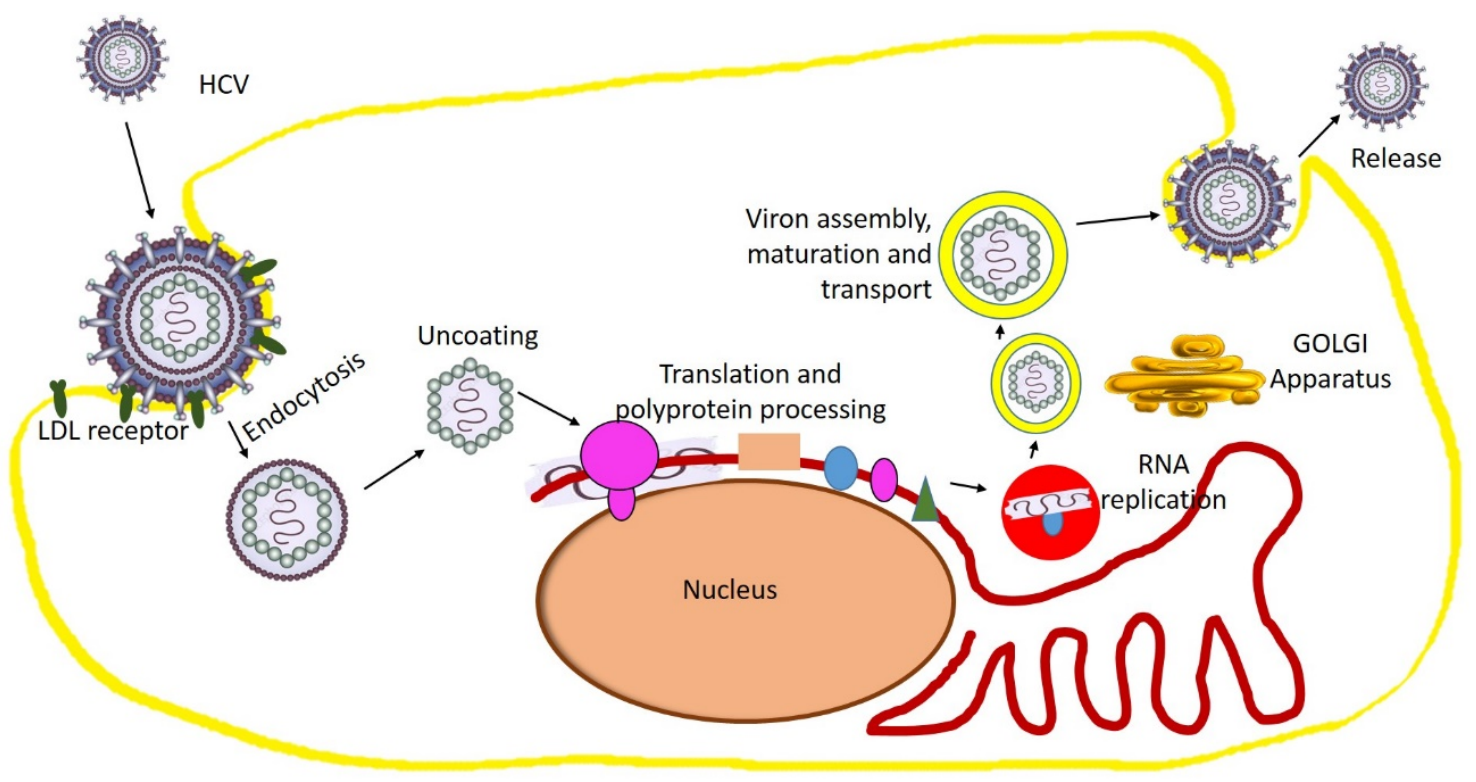

Figure 4. Hepatitis C virus structure and replication mechanism. The Ortomyxovirus structure in this figure has been modified from the source https://www.gettyimages.ae/.

There are synthetic agents available now against HCV, but they have a lack of specific treatment for HCV therapy. Another concern in these cases is the presence of severe side effects and reported poor response rates. To manage and to get these problems under control for better treatment against $\mathrm{HCV}$, new potential agents to be explored. As we see in the cases of other viruses discussed in the review, there are many promising natural products, which have led to the discovery of potent HCV inhibitors. A list of plant species with inhibition studies is summarized in Table 7. 
Table 7. Review of the plants that have shown anti-HCV activities with their prospective family, part, type of extract, and inhibition target.

\begin{tabular}{|c|c|c|c|c|c|c|}
\hline No. & Plant & Family & Part & Extract & Inhibition Target & Ref. \\
\hline 1 & Ajuga bracteosa & Lamiaceae & Leaves & Methanol & $\begin{array}{l}\text { HCV infection } \\
\text { Replication }\end{array}$ & {$[224]$} \\
\hline 2 & Ajuga parviflora & Lamiaceae & Leaves & Methanol & $\begin{array}{l}\text { HCV infection } \\
\text { Replication }\end{array}$ & {$[224]$} \\
\hline 3 & Berberis lycium & Lamiaceae & Roots & Methanol & $\begin{array}{l}\text { HCV infection } \\
\text { Replication }\end{array}$ & {$[224]$} \\
\hline 4 & Toona sureni & Meliaceae & Leaves & $80 \%$ Ethanol & $\begin{array}{l}\text { HCV infection } \\
\text { Replication }\end{array}$ & {$[225]$} \\
\hline 5 & Melicope latifolia & Rutaceae & Leaves & $80 \%$ Ethanol & $\begin{array}{l}\text { HCV infection } \\
\text { Replication }\end{array}$ & {$[225]$} \\
\hline 6 & Melanolepis multiglandulosa & Euphorbiaceae & Stems & $80 \%$ Ethanol & $\begin{array}{l}\text { HCV infection } \\
\text { Replication }\end{array}$ & {$[225]$} \\
\hline 7 & Ficus fistulosa & Moraceae & Leaves & $80 \%$ Ethanol & $\begin{array}{l}\text { HCV infection } \\
\text { Replication }\end{array}$ & {$[225]$} \\
\hline 8 & Phyllanthus amarus & Phyllanthaceae & Whole plant & Methanol & Inhibition of HCV RNA replication & [226] \\
\hline 9 & Acacia nilotica & Mimosaceae & Bark & Methanol & Hepatitis $\mathrm{C}$ virus (HCV) protease inhibition & {$[227]$} \\
\hline 10 & Boswellia carterii & Burseraceae & Root & Methanol & Hepatitis $\mathrm{C}$ virus (HCV) protease inhibition & {$[227]$} \\
\hline 11 & Embelia schimperi & Myrsinaceae & Fruit & Methanol & Hepatitis $\mathrm{C}$ virus (HCV) protease inhibition & {$[227]$} \\
\hline 12 & Piper cubeba & Piperaceae & Fruit & Aqueous & Hepatitis $\mathrm{C}$ virus (HCV) protease inhibition & [227] \\
\hline 13 & Quercus infectoria & Fagaceae & Gall & Methanol & Hepatitis $\mathrm{C}$ virus (HCV) protease inhibition & [227] \\
\hline 14 & Syzygium aromaticum & Myrtaceae & Fruit & Aqueous & Hepatitis $\mathrm{C}$ virus (HCV) protease inhibition & [227] \\
\hline 15 & Trachyspermum ammi & Apiaceae & Fruit & Methanol & Hepatitis $\mathrm{C}$ virus (HCV) protease inhibition & {$[227]$} \\
\hline 16 & Morinda citrifolia & Rubioideae & Leaves & Methanol & Hepatitis $\mathrm{C}$ virus (HCV) protease inhibition & [228] \\
\hline 17 & Silybum marianum & Asteraceae & Flower & Methanol & Hepatitis $\mathrm{C}$ virus (HCV) protease inhibition & [229] \\
\hline 18 & Limonium sinense & Plumbaginaceae & Flower & Aqueous & $\begin{array}{c}\text { HCV infection } \\
\text { Replication }\end{array}$ & {$[230]$} \\
\hline 19 & Bupleurum kaoi & Apiaceae & Root & Methanol & Inhibit HCV entry & {$[231]$} \\
\hline 20 & Rhizoma coptidis & Ranunculaceae & Whole & Methanol & Inhibit HCV entry & {$[232]$} \\
\hline 21 & Schisandra sphenanthera & Schisandraceae & Rhizome & Methanol & Inhibit HCV entry & {$[232]$} \\
\hline 22 & Solanum nigrum & Solanaceae & Seed & Chloroform & NS3 protease inhibition & {$[233]$} \\
\hline 23 & Terminalia arjuna & Combretaceae & Bark & Methanol & NS3 protease inhibition & [226] \\
\hline 24 & Embelia ribes & Myrsinaceae & Leaf & Aqueous & NS3 protease inhibition & {$[234]$} \\
\hline
\end{tabular}


Table 7. Cont.

\begin{tabular}{cccccc}
\hline No. & Plant & Family & Part & Extract & Inhibition Target \\
\hline 25 & Aeginetia indica & Orobanchaceae & Whole & Aqueous & NS5B polymerase inhibition \\
26 & Rhodiola kirilowii & Crassulaceae & Flower & Ethanol & NS3 protease inhibition \\
27 & Schisandra sphenanthera & Schisandraceae & Fruit & Ethanol & [235] \\
28 & Spatholobus suberectus & Fabaceae & Leaf & Ethanol & [236] \\
29 & Vitis vinifera & Vitaceae & Root & Ethanol & NS3 protease inhibition \\
30 & Cinnamomi cortex & Lauraceae & Bark & Methanol helicase inhibition & Inhibition of HCV replication and RNA \\
& & & & s237] & [239] \\
& & & &
\end{tabular}


Developing an anti-HCV drug has become an important priority due to the complexity of the disease. Natural compounds always serve as a lead to create new drugs. There is a substantial increase in the reports on phytochemicals that show anti-HCV properties. Both primary and secondary metabolites have shown promising activities. For instance, alkaloids, flavonoids, polyphenols, coumarins, and peptides have been reported to possess anti-HCV activities [241]. We have identified such molecules and listed them in Table 8.

Table 8. Bioactive compounds derived from plants with anti-HCV activities.

\begin{tabular}{|c|c|c|c|c|}
\hline No. & Compound & Activity & Dose/IC50 & Ref. \\
\hline 1 & Embelin & Hepatitis $\mathrm{C}$ virus (HCV) protease inhibition & $21 \mu \mathrm{M}$ & [227] \\
\hline 2 & Silymarin & NS5B polymerase inhibition & $40 \mu \mathrm{M}$ & [242] \\
\hline 3 & 5-O-Methylembelin & Hepatitis $\mathrm{C}$ virus $(\mathrm{HCV})$ protease inhibition & $46 \mu \mathrm{M}$ & [227] \\
\hline 4 & Pheophorbide a & Hepatitis $\mathrm{C}$ virus (HCV) protease inhibition & $0.3 \mu \mathrm{g} / \mathrm{mL}$ & [228] \\
\hline 5 & Pentagalloylglucose & Inhibit viral attachment & $2.2 \mu \mathrm{M}$ & [243] \\
\hline 6 & Quercetin & inhibitory effect of NS3 catalytic activity & $10 \mu \mathrm{g} / \mathrm{mL}$ & [234] \\
\hline 7 & Naringenin & Hepatitis $\mathrm{C}$ virus $(\mathrm{HCV})$ protease inhibition & $200 \mu \mathrm{M}$ & [244] \\
\hline 8 & $(+)$-Epicatechin & Inhibition of HCV replication & $75 \mu \mathrm{M}$ & [245] \\
\hline 9 & (-)-Epicatechin & Inhibition of HCV replication & $75 \mu \mathrm{M}$ & [245] \\
\hline 10 & Ladanein & inhibition of the post attachment entry step of $\mathrm{HCV}$ & $2.5 \mu \mathrm{M}$ & [246] \\
\hline 11 & Luteolin & $\begin{array}{l}\text { Inhibition of HCV infection } \\
\text { Replication in NS5B polymerase }\end{array}$ & $7.9 \mu \mathrm{M}$ & [247] \\
\hline 12 & Honokiol & $\begin{array}{l}\text { Inhibition of HCV infection } \\
\text { Replication in NS5B polymerase }\end{array}$ & $4.5 \mu \mathrm{M}$ & [248] \\
\hline 13 & 3-Hydroxy caruilignan $\mathrm{C}$ & Inhibition of HCV replication & $37.5 \mu \mathrm{M}$ & [249] \\
\hline 14 & Gallic acid & Inhibition of viral entry & $24.31 \mu \mathrm{M}$ & [230] \\
\hline 15 & Saikosaponin b2 & Inhibition of viral entry & $16.13 \mu \mathrm{M}$ & [231] \\
\hline 16 & Delphinidin & Inhibition of viral entry & $3.7 \mu \mathrm{M}$ & [250] \\
\hline 17 & Amentoflavone & Inhibition of viral entry & $42 \mu \mathrm{M}$ & [251] \\
\hline 18 & 7,40-Dihydroxyflavanone & Inhibition of viral entry & $42 \mu \mathrm{M}$ & [251] \\
\hline 19 & Orobol & Inhibition of viral entry & $42 \mu \mathrm{M}$ & [251] \\
\hline 20 & 3,3'-Digalloylproprodelphinidin & NS3 protease inhibition & $0.77 \mu \mathrm{M}$ & [236] \\
\hline 21 & B2, 3,3'-Digalloylprocyanidin & NS3 protease inhibition & $0.91 \mu \mathrm{M}$ & [236] \\
\hline 22 & $\begin{array}{c}\text { B2, (-)-Epigallocatechin-3-O-gallate, } \\
(-) \text {-Epicatechin- }\end{array}$ & NS3 protease inhibition & $8.51 \mu \mathrm{M}$ & [236] \\
\hline 23 & 3-O-gallate & NS3 protease inhibition & $18.55 \mu \mathrm{M}$ & [236] \\
\hline 24 & Schizandronic acid & Inhibition of HCV entry & $5.27 \mu \mathrm{g} / \mathrm{mL}$ & [237] \\
\hline 25 & Vitisin B & NS3 helicase inhibition & $0.006 \mu \mathrm{M}$ & [239] \\
\hline 26 & Procyanidin B1 & Inhibition of HCV replication and RNA synthesis & $29 \mu \mathrm{M}$ & [240] \\
\hline 27 & Plumbagin & $\begin{array}{l}\text { Inhibition of HCV infection } \\
\text { Replication in NS5B polymerase }\end{array}$ & $0.57 \mu \mathrm{M}$ & [252] \\
\hline 28 & Caffeine & $\begin{array}{l}\text { Inhibition of HCV infection } \\
\text { Replication in NS5B polymerase }\end{array}$ & $0.726 \mathrm{mM}$ & [253] \\
\hline 29 & Ursolic acid & $\begin{array}{l}\text { Inhibition of HCV infection } \\
\text { Replication in NS5B polymerase }\end{array}$ & $16 \mu \mathrm{g} / \mathrm{mL}$ & [254] \\
\hline
\end{tabular}

\section{Conclusions}

Viral infections and pandemic have been recorded as a potential risk for human survival. The lack of proper prophylactic vaccines and drugs for many viruses makes the situation worse in health management. There is a great need for novel antiviral compounds for drug development. This review provides in-depth and insightful information about different species of plants and their families with significant secondary metabolites with evidence-based antiviral properties. Based on the literature, we provided very promising drug candidates that have been investigated through in vitro screening, and cellular targets have been observed. In the current review, we have selected HIV, HSV, HCV and Influenza virus. Looking at the spectrum of plants and isolated compounds, we have seen that there is no significant selectivity among the plants and their compounds in inhibiting DNA or RNA virus. We have found that a similar class of phytochemicals can inhibit both types, but with the ability to inhibit different sites of mechanism. However, these compounds need a lot of further investigation to make them appropriate for clinical use. The pace of new antiviral drugs from natural origin has experienced a substantial upsurge in the last decade. Natural products directly or indirectly support the drug discovery against viruses. Many anti-viral drugs has been discovered from a synthetic source, but originally modeled on a natural product parent structure. Most of the plants we 
have identified in this review hold other pharmacological benefits, proven long ago, together with their safety profile. This promotes the acceptance of these plants and their phytochemicals for antiviral drug discovery and development programs. Nevertheless, a thorough purification process for identifying new lead compounds and their preclinical and safety testing is a prerequisite. The current COVID-19 pandemic has taught us a more significant lesson: it is difficult to survive in this earth without accepting the probability of more pandemics in the future. Hence, taking the facts in a very comprehensive manner, a cohesive and focused drug discovery approach is warranted.

Funding: This research received no external funding.

Acknowledgments: We would like to thank the deanship of scientific research at Jazan University.

Conflicts of Interest: The authors declare no conflict of interest

\section{References}

1. Wang, S.-X.; Wang, Y.; Lu, Y.-B.; Li, J.-Y.; Song, Y.-J.; Nyamgerelt, M.; Wang, X.-X. Diagnosis and treatment of novel coronavirus pneumonia based on the theory of traditional Chinese medicine. J. Integr. Med. 2020, 18, 275-283. [CrossRef]

2. Brito, A.F.; Pinney, J.W. Protein-protein interactions in virus-host systems. Front. Microbiol. 2017, 8, 1557. [CrossRef] [PubMed]

3. Virgin, H.W.; Wherry, E.J.; Ahmed, R. Redefining chronic viral infection. Cell 2009, 138, 30-50. [CrossRef] [PubMed]

4. Deigendesch, N.; Stenzel, W. Acute and chronic viral infections. In Handbook of Clinical Neurology; Elsevier: Amsterdam, The Nederlands, 2018; Volume 145, pp. 227-243.

5. Bhutta, Z.A.; Sommerfeld, J.; Lassi, Z.S.; Salam, R.A.; Das, J.K. Global burden, distribution, and interventions for infectious diseases of poverty. Infect. Dis. Poverty 2014, 3, 21. [CrossRef] [PubMed]

6. Ribeiro, R.M.; Bonhoeffer, S.; Nowak, M.A. The frequency of resistant mutant virus before antiviral therapy. AIDS 1998, 12, 461-465. [CrossRef]

7. Martinez, J.; Sasse, F.; Brönstrup, M.; Diez, J.; Meyerhans, A. Antiviral drug discovery: Broad-spectrum drugs from nature. Nat. Prod. Rep. 2015, 32, 29-48. [CrossRef] [PubMed]

8. Farnsworth, N.R.; Akerele, O.; Bingel, A.S.; Soejarto, D.D.; Guo, Z. Medicinal plants in therapy. Bull. World Health Organ. 1985, 63, 965. [CrossRef]

9. Solecki, R.S. Shanidar IV, a Neanderthal flower burial in northern Iraq. Science 1975, 190, 880-881. [CrossRef]

10. Pandey, A.; Galvani, A.P. The global burden of HIV and prospects for control. Lancet HIV 2019, 6, e809-e811. [CrossRef]

11. Lazarus, J.V.; Safreed-Harmon, K.; Barton, S.E.; Costagliola, D.; Dedes, N.; del Amo Valero, J.; Gatell, J.M.; Baptista-Leite, R.; Mendão, L.; Porter, K. Beyond viral suppression of HIV-The new quality of life frontier. BMC Med. 2016, 14, 94. [CrossRef]

12. Frank, T.D.; Carter, A.; Jahagirdar, D.; Biehl, M.H.; Douwes-Schultz, D.; Larson, S.L.; Arora, M.; Dwyer-Lindgren, L.; Steuben, K.M.; Abbastabar, H. Global, regional, and national incidence, prevalence, and mortality of HIV, 1980-2017, and forecasts to 2030, for 195 countries and territories: A systematic analysis for the Global Burden of Diseases, Injuries, and Risk Factors Study 2017. Lancet HIV 2019, 6, e831-e859. [CrossRef]

13. International Committee on Taxonomy of Viruses. 61.0.6. Lentivirus. National Institutes of Health. Available online: http://www.ncbi.nlm.nih.gov/ICTVdb/ICTVdB/61060000.htm (accessed on 9 October 2020).

14. Soudeyns, H.; Champagne, P.; Holloway, C.L.; Silvestri, G.U.; Ringuette, N.; Samson, J.; Lapointe, N.; Sékaly, R.-P. Transient T cell receptor $\beta$-chain variable region-specific expansions of CD4+ and CD8+ T cells during the early phase of pediatric human immunodeficiency virus infection: Characterization of expanded cell populations by T cell receptor phenotyping. J. Infect. Dis. 2000, 181, 107-120. [CrossRef] [PubMed]

15. Varmus, H. Regulation of HIV and HTLV gene expression. Genes Dev. 1988, 2, 1055-1062. [CrossRef]

16. Yang, S.S.; Cragg, G.M.; Newman, D.J.; Bader, J.P. Natural product-based anti-HIV drug discovery and development facilitated by the NCI developmental therapeutics program. J. Nat. Prod. 2001, 64, 265-277. [CrossRef] [PubMed] 
17. Vaishnav, Y.N.; Wong-Staal, F. The biochemistry of AIDS. Annu. Rev. Biochem. 1991, 60, 577-630. [CrossRef] [PubMed]

18. Kuznetsov, Y.G.; McPherson, A. Atomic force microscopy in imaging of viruses and virus-infected cells. Microbiol. Mol. Biol. Rev. 2011, 75, 268-285. [CrossRef]

19. Tanser, F.; Bärnighausen, T.; Grapsa, E.; Zaidi, J.; Newell, M.-L. High coverage of ART associated with decline in risk of HIV acquisition in rural KwaZulu-Natal, South Africa. Science 2013, 339, 966-971. [CrossRef]

20. Bangsberg, D.R.; Kroetz, D.L.; Deeks, S.G. Adherence-resistance relationships to combination HIV antiretroviral therapy. Curr. HIV/AIDS Rep. 2007, 4, 65. [CrossRef]

21. Bock, C.; Lengauer, T. Managing drug resistance in cancer: Lessons from HIV therapy. Nat. Rev. Cancer 2012, 12, 494-501. [CrossRef]

22. Cragg, G.; Newman, D. Plants as a source of anti-cancer and anti-HIV agents. Ann. Appl. Biol. 2003, 143, 127-133. [CrossRef]

23. Barreca, M.L.; Ferro, S.; Rao, A.; De Luca, L.; Zappalà, M.; Monforte, A.-M.; Debyser, Z.; Witvrouw, M.; Chimirri, A. Pharmacophore-based design of HIV-1 integrase strand-transfer inhibitors. J. Med. Chem. 2005, 48, 7084-7088. [CrossRef] [PubMed]

24. De Clercq, E. The role of non-nucleoside reverse transcriptase inhibitors (NNRTIs) in the therapy of HIV-1 infection. Antivir. Res. 1998, 38, 153-179. [CrossRef]

25. Nair, V.; Chi, G. HIV integrase inhibitors as therapeutic agents in AIDS. Rev. Med Virol. 2007, 17, $277-295$. [CrossRef] [PubMed]

26. Meixenberger, K.; Yousef, K.P.; Smith, M.R.; Somogyi, S.; Fiedler, S.; Bartmeyer, B.; Hamouda, O.; Bannert, N.; von Kleist, M.; Kücherer, C. Molecular evolution of HIV-1 integrase during the 20 years prior to the first approval of integrase inhibitors. Virol. J. 2017, 14, 223. [CrossRef]

27. Tewtrakul, S.; Subhadhirasakul, S.; Kummee, S. Anti-HIV-1 integrase activity of medicinal plants used as self medication by AIDS patients. Songklanakarin J. Sci. Technol. 2006, 28, 785-790.

28. Basu, V.P.; Song, M.; Gao, L.; Rigby, S.T.; Hanson, M.N.; Bambara, R.A. Strand transfer events during HIV-1 reverse transcription. Virus Res. 2008, 134, 19-38. [CrossRef]

29. Flexner, C. HIV-protease inhibitors. N. Engl. J. Med. 1998, 338, 1281-1293. [CrossRef]

30. Gills, J.J.; LoPiccolo, J.; Tsurutani, J.; Shoemaker, R.H.; Best, C.J.; Abu-Asab, M.S.; Borojerdi, J.; Warfel, N.A.; Gardner, E.R.; Danish, M. Nelfinavir, A lead HIV protease inhibitor, is a broad-spectrum, anticancer agent that induces endoplasmic reticulum stress, autophagy, and apoptosis in vitro and in vivo. Clin. Cancer Res. 2007, 13, 5183-5194. [CrossRef]

31. Siwe-Noundou, X.; Ndinteh, D.; Olivier, D.; Mnkandhla, D.; Isaacs, M.; Muganza, F.; Mbafor, J.; Van Vuuren, S.; Patnala, S.; Hoppe, H. Biological activity of plant extracts and isolated compounds from Alchornea laxiflora: Anti-HIV, antibacterial and cytotoxicity evaluation. S. Afr. J. Bot. 2019, 122, 498-503. [CrossRef]

32. Suedee, A.; Tewtrakul, S.; Panichayupakaranant, P. Anti-HIV-1 integrase activity of Mimusops elengi leaf extracts. Pharm. Biol. 2014, 52, 58-61. [CrossRef]

33. Kapewangolo, P.; Tawha, T.; Nawinda, T.; Knott, M.; Hans, R. Sceletium tortuosum demonstrates in vitro anti-HIV and free radical scavenging activity. S. Afr. J. Bot. 2016, 106, 140-143. [CrossRef]

34. Kapewangolo, P.; Knott, M.; Shithigona, R.E.; Uusiku, S.L.; Kandawa-Schulz, M. In vitro anti-HIV and antioxidant activity of Hoodia gordonii (Apocynaceae), a commercial plant product. BMC Complement. Altern. Med. 2016, 16, 1-7. [CrossRef]

35. Au, T.; Lam, T.; Ng, T.; Fong, W.; Wan, D. A comparison of HIV-1 integrase inhibition by aqueous and methanol extracts of Chinese medicinal herbs. Life Sci. 2001, 68, 1687-1694. [CrossRef]

36. Bunluepuech, K.; Tewtrakul, S. Anti-HIV-1 integrase activity of Thai medicinal plants in longevity preparations. Sonklanakarin J. Sci. Technol. 2011, 33, 693.

37. Lee, J.S.; Kim, H.J.; Lee, Y.S. A new anti-HIV flavonoid glucuronide from Chrysanthemum morifolium. Planta Med. 2003, 69, 859-861. [PubMed]

38. Matsuse, I.; Lim, Y.; Hattori, M.; Correa, M.; Gupta, M. A search for anti-viral properties in Panamanian medicinal plants: The effects on HIV and its essential enzymes. J. Ethnopharmacol. 1998, 64, 15-22. [CrossRef]

39. Narayan, C.; Rai, R.V.; Tewtrakul, S. A screening strategy for selection of anti-HIV-1 integrase and anti-HIV-1 protease inhibitors from extracts of Indian medicinal plants. Int. J. Phytomed. 2011, 3, 312.

40. Chaniad, P.; Wattanapiromsakul, C.; Pianwanit, S.; Tewtrakul, S. Anti-HIV-1 integrase compounds from Dioscorea bulbifera and molecular docking study. Pharm. Biol. 2016, 54, 1077-1085. [CrossRef] 
41. Kim, H.K.; Lee, H.-K.; Shin, C.-G.; Huh, H. HIV integrase inhibitory activity ofAgastache rugosa. Arch. Pharmacal Res. 1999, 22, 520-523. [CrossRef]

42. Geuenich, S.; Goffinet, C.; Venzke, S.; Nolkemper, S.; Baumann, I.; Plinkert, P.; Reichling, J.; Keppler, O.T. Aqueous extracts from peppermint, sage and lemon balm leaves display potent anti-HIV-1 activity by increasing the virion density. Retrovirology 2008, 5, 27. [CrossRef]

43. Min, B.S.; Bae, K.H.; Kim, Y.H.; Shimotono, K.; Miyashiro, H.; Hattori, M. Inhibitory activities of Korean plants on HIV-1 protease. Nat. Prod. Sci. 1998, 4, 241-244.

44. Eid, A.M.M.; Elmarzugi, N.A.; El-Enshasy, H.A. A review on the phytopharmacological effect of Swietenia macrophylla. Int. J. Pharm. Pharm. Sci. 2013, 3, 5.

45. Asres, K.; Bucar, F.; Kartnig, T.; Witvrouw, M.; Pannecouque, C.; De Clercq, E. Antiviral activity against human immunodeficiency virus type 1 (HIV-1) and type 2 (HIV-2) of ethnobotanically selected Ethiopian medicinal plants. Phytother. Res. Int. J. Devoted Pharmacol. Toxicol. Eval. Nat. Prod. Deriv. 2001, 15, 62-69. [CrossRef]

46. Rege, A.A.; Ambaye, R.Y.; Deshmukh, R.A. Evaluation of in vitro inhibitory effect of selected plants and Shilajit on HIV-reverse transcriptase. Indian J. Nat. Prod. Resour. 2012, 3, 145-151.

47. Woradulayapinij, W.; Soonthornchareonnon, N.; Wiwat, C. In vitro HIV type 1 reverse transcriptase inhibitory activities of Thai medicinal plants and Canna indica L. rhizomes. J. Ethnopharmacol. 2005, 101, 84-89. [CrossRef]

48. Silprasit, K.; Seetaha, S.; Pongsanarakul, P.; Hannongbua, S.; Choowongkomon, K. Anti-HIV-1 reverse transcriptase activities of hexane extracts from some Asian medicinal plants. J. Med. Plants Res 2011, 5, 4194-4201.

49. Grzybek, J.; Wongpanich, V.; Mata-Greenwood, E.; Angerhofer, C.K.; Pezzuto, J.M.; Cordell, G.A. Biological evaluation of selected plants from Poland. Int. J. Pharm. 1997, 35, 1-5. [CrossRef]

50. Mlinaric, A.; Kreft, S.; Umek, A.; Strukelj, B. Screening of selected plant extracts for in vitro inhibitory activity on HIV-1 reverse transcriptase (HIV-1 RT). Die Pharm. 2000, 55, 75-77.

51. Gujjeti, R.P.; Mamidala, E. Anti-HIV activity of phytosterol isolated from Aerva lanata roots. Pharm. J. 2017, 9, 112-116. [CrossRef]

52. Ali, H.; König, G.; Khalid, S.; Wright, A.; Kaminsky, R. Evaluation of selected Sudanese medicinal plants for their in vitro activity against hemoflagellates, selected bacteria, HIV-1-RT and tyrosine kinase inhibitory, and for cytotoxicity. J. Ethnopharmacol. 2002, 83, 219-228. [CrossRef]

53. McMahon, J.B.; Currens, M.J.; Gulakowski, R.J.; Buckheit, R.; Lackman-Smith, C.; Hallock, Y.F.; Boyd, M.R. Michellamine B, a novel plant alkaloid, inhibits human immunodeficiency virus-induced cell killing by at least two distinct mechanisms. Antimicrob. Agents Chemother. 1995, 39, 484-488. [CrossRef] [PubMed]

54. Bicchi, C.; Rubiolo, P.; Ballero, M.; Sanna, C.; Matteodo, M.; Esposito, F.; Zinzula, L.; Tramontano, E. HIV-1-inhibiting activity of the essential oil of Ridolfia segetum and Oenanthe crocata. Planta Med. 2009, 75, 1331-1335. [CrossRef] [PubMed]

55. Esposito, F.; Mandrone, M.; Del Vecchio, C.; Carli, I.; Distinto, S.; Corona, A.; Lianza, M.; Piano, D.; Tacchini, M.; Maccioni, E. Multi-target activity of Hemidesmus indicus decoction against innovative HIV-1 drug targets and characterization of Lupeol mode of action. Pathog. Dis. 2017, 75, ftx065. [CrossRef]

56. Rukunga, G.M.; Kofi-Tsekpo, M.W.; Kurokawa, M.; Kageyama, S.; Mungai, G.M.; Muli, J.M.; Tolo, F.M.; Kibaya, R.M.; Muthaura, C.N.; Kanyara, J.N. Evaluation of the HIV-1 reverse transcriptase inhibitory properties of extracts from some medicinal plants in Kenya. Afr. J. Health Sci. 2002, 9, 81-90. [CrossRef]

57. Chukwujekwu, J.; Ndhlala, A.; De Kock, C.; Smith, P.; Van Staden, J. Antiplasmodial, HIV-1 reverse transcriptase inhibitory and cytotoxicity properties of Centratherum punctatum Cass. and its fractions. S. Afr. J. Bot. 2014, 90, 17-19. [CrossRef]

58. Hnatyszyn, O.; Broussalis, A.; Herrera, G.; Muschietti, L.; Coussio, J.; Martino, V.; Ferraro, G.; Font, M.; Monge, A.; Martínez-Irujo, J.J. Argentine plant extracts active against polymerase and ribonuclease $\mathrm{H}$ activities of HIV-1 reverse transcriptase. Phytother. Res. 1999, 13, 206-209. [CrossRef]

59. Harnett, S.; Oosthuizen, V.D.V.; Van de Venter, M. Anti-HIV activities of organic and aqueous extracts of Sutherlandia frutescens and Lobostemon trigonus. J. Ethnopharmacol. 2005, 96, 113-119. [CrossRef]

60. Bedoya, L.M.; Beltrán, M.; Sancho, R.; Olmedo, D.A.; Sánchez-Palomino, S.; del Olmo, E.; López-Pérez, J.L.; Muñoz, E.; San Feliciano, A.; Alcamí, J. 4-Phenylcoumarins as HIV transcription inhibitors. Bioorganic Med. Chem. Lett. 2005, 15, 4447-4450. [CrossRef] 
61. Chang, C.-W.; Lin, M.-T.; Lee, S.-S.; Liu, K.C.C.; Hsu, F.-L.; Lin, J.-Y. Differential inhibition of reverse transcriptase and cellular DNA polymerase- $\alpha$ activities by lignans isolated from Chinese herbs, Phyllanthus myrtifolius Moon, and tannins from Lonicera japonica Thunb and Castanopsis hystrix. Antivir. Res. 1995, 27, 367-374. [CrossRef]

62. Bessong, P.O.; Obi, C.L.; Andréola, M.-L.; Rojas, L.B.; Pouységu, L.; Igumbor, E.; Meyer, J.M.; Quideau, S.; Litvak, S. Evaluation of selected South African medicinal plants for inhibitory properties against human immunodeficiency virus type 1 reverse transcriptase and integrase. J. Ethnopharmacol. 2005, 99, 83-91. [CrossRef]

63. Mamidala, E.; Paindla, P.; Gurrapu, S. Hiv-1 Reverse Transcriptase Inhibition by Phenolic Compounds Isolated From Acalypha Indica (L.) Plant Leaves Extract. Int. J. Appl. Bioeng. 2017, 11, 17-21.

64. Fang, E.F.; Lin, P.; Wong, J.H.; Tsao, S.W.; Ng, T.B. A lectin with anti-HIV-1 reverse transcriptase, antitumor, and nitric oxide inducing activities from seeds of Phaseolus vulgaris cv. extralong autumn purple bean. J. Agric. Food Chem. 2010, 58, 2221-2229. [CrossRef]

65. Thayil Seema, M.; Thyagarajan, S. Methanol and aqueous extracts of Ocimum kilimandscharicum (Karpuratulasi) inhibits HIV-1 reverse transcriptase in vitro. Int. J. Pharm. Pharmacogn. Res. 2016, 8, 1099-1103.

66. Lavignon, M.; Bertrand, J.-R.; Rayner, B.; Imbach, J.-L.; Malvy, C.; Paoletti, C. Inhibition of Moloney murine leukemia virus reverse transcriptase by $\alpha$-anomeric oligonucleotides. Biochem. Biophys. Res. Commun. 1989, 161, 1184-1190. [CrossRef]

67. Esposito, F.; Sanna, C.; Del Vecchio, C.; Cannas, V.; Venditti, A.; Corona, A.; Bianco, A.; Serrilli, A.M.; Guarcini, L.; Parolin, C. Hypericum hircinum L. components as new single-molecule inhibitors of both HIV-1 reverse transcriptase-associated DNA polymerase and ribonuclease H activities. Pathog. Dis. 2013, 68, 116-124. [CrossRef] [PubMed]

68. Alam, M.S.; Quader, M.; Rashid, M. HIV-inhibitory diterpenoid from Anisomeles indica. Fitoterapia 2000, 71, 574-576. [CrossRef]

69. Miraj, S.; Azizi, N.; Kiani, S. A review of chemical components and pharmacological effects of Melissa officinalis L. Pharm. Lett. 2016, 8, 229-237.

70. Kapewangolo, P.; Omolo, J.J.; Fonteh, P.; Kandawa-Schulz, M.; Meyer, D. Triterpenoids from Ocimum labiatum activates latent HIV-1 expression in vitro: Potential for use in adjuvant therapy. Molecules 2017, 22, 1703. [CrossRef]

71. Hatano, T.; Yasuhara, T.; Matsuda, M.; Yazaki, K.; Yoshida, T.; Okuda, T. Oenothein B, a dimeric hydrolyzable tannin of cyclic structure. Chem. Pharm. Bull. 1989, 37, 2269-2271. [CrossRef]

72. Ogata, T.; Higuchi, H.; Mochida, S.; Matsumoto, H.; Kato, A.; Endo, T.; Kaji, A.; Kaji, H. HIV-1 reverse transcriptase inhibitor from Phyllanthus niruri. Aids Res. Hum. Retrovir. 1992, 8, 1937-1944. [CrossRef]

73. Esposito, F.; Carli, I.; Del Vecchio, C.; Xu, L.; Corona, A.; Grandi, N.; Piano, D.; Maccioni, E.; Distinto, S.; Parolin, C. Sennoside A, derived from the traditional Chinese medicine plant Rheum L. is a new dual HIV-1 inhibitor effective on HIV-1 replication. Phytomedicine 2016, 23, 1383-1391. [CrossRef] [PubMed]

74. Reutrakul, V.; Krachangchaeng, C.; Tuchinda, P.; Pohmakotr, M.; Jaipetch, T.; Yoosook, C.; Kasisit, J.; Sophasan, S.; Sujarit, K.; Santisuk, T. Cytotoxic and anti-HIV-1 constituents from leaves and twigs of Gardenia tubifera. Tetrahedron 2004, 60, 1517-1523. [CrossRef]

75. Xu, H.X.; Wan, M.; Loh, B.N.; Kon, O.L.; Chow, P.W.; Sim, K.Y. Screening of Traditional Medicines for their Inhibitory Activity against HIV-1 Protease. Phytother. Res. 1996, 10, 207-210. [CrossRef]

76. Kusumoto, I.T.; Nakabayashi, T.; Kida, H.; Miyashiro, H.; Hattori, M.; Namba, T.; Shimotohno, K. Screening of various plant extracts used in ayurvedic medicine for inhibitory effects on human immunodeficiency virus type 1 (HIV-1) protease. Phytother. Res. 1995, 9, 180-184. [CrossRef]

77. Tewtrakul, S.; Subhadhirasakul, S.; Cheenpracha, S.; Karalai, C. HIV-1 protease and HIV-1 integrase inhibitory substances from Eclipta prostrata. Phytother. Res. Int. J. Devoted Pharmacol. Toxicol. Eval. Nat. Prod. Deriv. 2007, 21, 1092-1095.

78. Min, B.S.; Bae, K.H.; Kim, Y.H.; Miyashiro, H.; Hattori, M.; Shimotohno, K. Screening of Korean plants against human immunodeficiency virus type 1 protease. Phytother. Res. Int. J. Devoted Pharmacol. Toxicol. Eval. Nat. Prod. Deriv. 1999, 13, 680-682. [CrossRef] 
79. Chingwaru, W.; Vidmar, J.; Kapewangolo, P.T. The potential of sub-saharan african plants in the management of human immunodeficiency virus infections: A review. Phytother. Res. 2015, 29, 1452-1487. [CrossRef] [PubMed]

80. Magadula, J.J.; Tewtrakul, S. Anti-HIV-1 protease activities of crude extracts of some Garcinia species growing in Tanzania. Afr. J. Biotechnol. 2010, 9. [CrossRef]

81. Asres, K.; Seyoum, A.; Veeresham, C.; Bucar, F.; Gibbons, S. Naturally derived anti-HIV agents. Phytother. Res. Int. J. Devoted Pharmacol. Toxicol. Eval. Nat. Prod. Deriv. 2005, 19, 557-581. [CrossRef]

82. Zhang, C.-F.; Nakamura, N.; Tewtrakul, S.; Hattori, M.; Sun, Q.-S.; Wang, Z.-T.; Fujiwara, T. Sesquiterpenes and alkaloids from Lindera chunii and their inhibitory activities against HIV-1 integrase. Chem. Pharm. Bull. 2002, 50, 1195-1200. [CrossRef]

83. Jiang, C.; Luo, P.; Zhao, Y.; Hong, J.; Morris-Natschke, S.L.; Xu, J.; Chen, C.-H.; Lee, K.-H.; Gu, Q. Carolignans from the aerial parts of Euphorbia sikkimensis and their anti-HIV activity. J. Nat. Prod. 2016, 79, 578-583. [CrossRef]

84. Modi, M.; Dezzutti, C.S.; Kulshreshtha, S.; Rawat, A.K.S.; Srivastava, S.K.; Malhotra, S.; Verma, A.; Ranga, U.; Gupta, S.K. Extracts from Acacia catechu suppress HIV-1 replication by inhibiting the activities of the viral protease and Tat. Virol. J. 2013, 10, 309.

85. Wang, H.; $\mathrm{Ng}$, T. Ascalin, a new anti-fungal peptide with human immunodeficiency virus type 1 reverse transcriptase-inhibiting activity from shallot bulbs. Peptides 2002, 23, 1025-1029. [CrossRef]

86. Gómez-Cansino, R.; Espitia-Pinzón, C.I.; Campos-Lara, M.G.; Guzmán-Gutiérrez, S.L.; Segura-Salinas, E.; Echeverría-Valencia, G.; Torras-Claveria, L.; Cuevas-Figueroa, X.M.; Reyes-Chilpa, R. Antimycobacterial and HIV-1 reverse transcriptase activity of Julianaceae and Clusiaceae plant species from Mexico. Evid. Based Complement. Altern. Med. 2015. [CrossRef] [PubMed]

87. Narayan, L.C.; Rai, V.R.; Tewtrakul, S. Emerging need to use phytopharmaceuticals in the treatment of HIV. J. Pharm. Res. 2013, 6, 218-223. [CrossRef]

88. Kuo, R.-Y.; Qian, K.; Morris-Natschke, S.L.; Lee, K.-H. Plant-derived triterpenoids and analogues as antitumor and anti-HIV agents. Nat. Prod. Rep. 2009, 26, 1321-1344. [CrossRef] [PubMed]

89. Bringmann, G.; Steinert, C.; Feineis, D.; Mudogo, V.; Betzin, J.; Scheller, C. HIV-inhibitory michellamine-type dimeric naphthylisoquinoline alkaloids from the Central African liana Ancistrocladus congolensis. Phytochemistry 2016, 128, 71-81. [CrossRef]

90. Tietjen, I.; Gatonye, T.; Ngwenya, B.N.; Namushe, A.; Simonambanga, S.; Muzila, M.; Mwimanzi, P.; Xiao, J.; Fedida, D.; Brumme, Z.L. Croton megalobotrys Müll Arg. and Vitex doniana (Sweet): Traditional medicinal plants in a three-step treatment regimen that inhibit in vitro replication of HIV-1. J. Ethnopharmacol. 2016, 191, 331-340. [CrossRef] [PubMed]

91. Sanna, C.; Rigano, D.; Corona, A.; Piano, D.; Formisano, C.; Farci, D.; Franzini, G.; Ballero, M.; Chianese, G.; Tramontano, E. Dual HIV-1 reverse transcriptase and integrase inhibitors from Limonium morisianum Arrigoni, an endemic species of Sardinia (Italy). Nat. Prod. Res. 2019, 33, 1798-1803. [CrossRef]

92. Hisayoshi, T.; Shinomura, M.; Yokokawa, K.; Kuze, I.; Konishi, A.; Kawaji, K.; Kodama, E.N.; Hata, K.; Takahashi, S.; Nirasawa, S. Inhibition of the DNA polymerase and RNase H activities of HIV-1 reverse transcriptase and HIV-1 replication by Brasenia schreberi (Junsai) and Petasites japonicus (Fuki) components. J. Nat. Med. 2015, 69, 432-440. [CrossRef] [PubMed]

93. Wang, Q.; Ding, Z.-H.; Liu, J.-K.; Zheng, Y.-T. Xanthohumol, a novel anti-HIV-1 agent purified from Hops Humulus lupulus. Antivir. Res. 2004, 64, 189-194. [CrossRef]

94. Zhang, H.; Ma, Z.F. Phytochemical and pharmacological properties of Capparis spinosa as a medicinal plant. Nutrients 2018, 10, 116. [CrossRef] [PubMed]

95. Singh, I.P.; Bharate, S.B.; Bhutani, K. Anti-HIV natural products. Curr. Sci. 2005, 89, 269-290.

96. Pailee, P.; Kuhakarn, C.; Sangsuwan, C.; Hongthong, S.; Piyachaturawat, P.; Suksen, K.; Jariyawat, S.; Akkarawongsapat, R.; Limthongkul, J.; Napaswad, C. Anti-HIV and cytotoxic biphenyls, benzophenones and xanthones from stems, leaves and twigs of Garcinia speciosa. Phytochemistry 2018, 147, 68-79. [CrossRef] [PubMed]

97. Chaturonrutsamee, S.; Kuhakarn, C.; Surawatanawong, P.; Prabpai, S.; Kongsaeree, P.; Jaipetch, T.; Piyachaturawat, P.; Jariyawat, S.; Akkarawongsapat, R.; Suksen, K. Polycyclic polyprenylated acylphloroglucinols and biphenyl derivatives from the roots of Garcinia nuntasaenii Ngerns. \& Suddee. Phytochemistry 2018, 146, 63-74. [PubMed] 
98. Palamthodi, S.; Lele, S. Nutraceutical applications of gourd family vegetables: Benincasa hispida, Lagenaria siceraria and Momordica charantia. Biomed. Prev. Nutr. 2014, 4, 15-21. [CrossRef]

99. Bekut, M.; Brkić, S.; Kladar, N.; Dragović, G.; Gavarić, N.; Božin, B. Potential of selected Lamiaceae plants in anti (retro) viral therapy. Pharmacol. Res. 2018, 133, 301-314. [CrossRef]

100. Zhao, Q.; Chen, X.-Y.; Martin, C. Scutellaria baicalensis, the golden herb from the garden of Chinese medicinal plants. Sci. Bull. 2016, 61, 1391-1398. [CrossRef] [PubMed]

101. Looker, K.J.; Welton, N.J.; Sabin, K.M.; Dalal, S.; Vickerman, P.; Turner, K.M.; Boily, M.-C.; Gottlieb, S.L. Global and regional estimates of the contribution of herpes simplex virus type 2 infection to HIV incidence: A population attributable fraction analysis using published epidemiological data. Lancet Infect. Dis. 2020, 20, 240-249. [CrossRef]

102. Whitley, R.J.; Roizman, B. Herpes simplex virus infections. The lancet 2001, 357, 1513-1518. [CrossRef]

103. Forni, D.; Pontremoli, C.; Clerici, M.; Pozzoli, U.; Cagliani, R.; Sironi, M. Recent out-of-Africa migration of human herpes simplex viruses. Mol. Biol. Evol. 2020, 37, 1259-1271. [CrossRef] [PubMed]

104. Dropulic, L.K.; Cohen, J.I. Update on new antivirals under development for the treatment of double-stranded DNA virus infections. Clin. Pharmacol. Ther. 2010, 88, 610-619. [CrossRef]

105. van den Pol, A.N.; Ozduman, K.; Wollmann, G.; Ho, W.S.; Simon, I.; Yao, Y.; Rose, J.K.; Ghosh, P. Viral strategies for studying the brain, including a replication-restricted self-amplifying delta-G vesicular stomatis virus that rapidly expresses transgenes in brain and can generate a multicolor Golgi-like expression. J. Comp. Neurol. 2009, 516, 456-481. [CrossRef]

106. Chuanasa, T.; Phromjai, J.; Lipipun, V.; Likhitwitayawuid, K.; Suzuki, M.; Pramyothin, P.; Hattori, M.; Shiraki, K. Anti-herpes simplex virus (HSV-1) activity of oxyresveratrol derived from Thai medicinal plant: Mechanism of action and therapeutic efficacy on cutaneous HSV-1 infection in mice. Antivir. Res. 2008, 80, 62-70. [CrossRef] [PubMed]

107. Neyts, J.; De Clercq, E. Mechanism of action of acyclic nucleoside phosphonates against herpes virus replication. Biochem. Pharmacol. 1994, 47, 39-41. [CrossRef]

108. Hassan, S.T.; Masarčíková, R.; Berchová, K. Bioactive natural products with anti-herpes simplex virus properties. J. Pharm. Pharmacol. 2015, 67, 1325-1336. [CrossRef] [PubMed]

109. Brady, R.C.; Bernstein, D.I. Treatment of herpes simplex virus infections. Antivir. Res. 2004, 61, 73-81. [CrossRef]

110. Corey, L. Challenges in genital herpes simplex virus management. J. Infect. Dis. 2002, 186 (Suppl. 1), S29-S33. [CrossRef]

111. Benzekri, R.; Limam, F.; Bouslama, L. Combination effect of three anti-HSV-2 active plant extracts exhibiting different modes of action. Adv. Tradit. Med. 2020, 20, 223-231. [CrossRef]

112. Musarra-Pizzo, M.; Pennisi, R.; Ben-Amor, I.; Smeriglio, A.; Mandalari, G.; Sciortino, M.T. In Vitro Anti-HSV-1 Activity of Polyphenol-Rich Extracts and Pure Polyphenol Compounds Derived from Pistachios Kernels (Pistacia vera L.). Plants 2020, 9, 267. [CrossRef]

113. Reichling, J.; Neuner, A.; Sharaf, M.; Harkenthal, M.; Schnitzler, P. Antiviral activity of Rhus aromatica (fragrant sumac) extract against two types of herpes simplex viruses in cell culture. Die Pharm. Int. J. Pharm. Sci. 2009, $64,538-541$.

114. Karimi, A.; Rafieian-Kopaei, M.; Moradi, M.-T.; Alidadi, S. Anti-Herpes Simplex Virus Type-1 Activity and Phenolic Content of Crude Ethanol Extract and Four Corresponding Fractions of Quercus brantii L Acorn. J. Evid. Based Complement. Altern. Med. 2017, 22, 455-461. [CrossRef] [PubMed]

115. Benassi-Zanqueta, É.; Marques, C.F.; Valone, L.M.; Pellegrini, B.L.; Bauermeister, A.; Ferreira, I.C.P.; Lopes, N.P.; Nakamura, C.V.; Dias Filho, B.P.; Natali, M.R.M. Evaluation of anti-HSV-1 activity and toxicity of hydroethanolic extract of Tanacetum parthenium (L.) Sch. Bip. (Asteraceae). Phytomedicine 2019, 55, 249-254. [CrossRef]

116. Yoosook, C.; Bunyapraphatsara, N.; Boonyakiat, Y.; Kantasuk, C. Anti-herpes simplex virus activities of crude water extracts of Thai medicinal plants. Phytomedicine 2000, 6, 411-419. [CrossRef]

117. Shamsabadipour, S.; Ghanadian, M.; Saeedi, H.; Rahimnejad, M.R.; Mohammadi-Kamalabadi, M.; Ayatollahi, S.M.; Salimzadeh, L. Triterpenes and steroids from Euphorbia denticulata Lam. with anti-Herpes symplex virus activity. Iran. J. Pharm. Res. IJPR 2013, 12, 759. 
118. Lipipun, V.; Kurokawa, M.; Suttisri, R.; Taweechotipatr, P.; Pramyothin, P.; Hattori, M.; Shiraki, K. Efficacy of Thai medicinal plant extracts against herpes simplex virus type 1 infection in vitro and in vivo. Antivir. Res. 2003, 60, 175-180. [CrossRef]

119. El-Toumy, S.A.; Salib, J.Y.; El-Kashak, W.A.; Marty, C.; Bedoux, G.; Bourgougnon, N. Antiviral effect of polyphenol rich plant extracts on herpes simplex virus type 1. Food Sci. Hum. Wellness 2018, 7, 91-101. [CrossRef]

120. Palomino, S.S.; Abad, M.J.; Bedoya, L.M.; García, J.; Gonzales, E.; Chiriboga, X.; Bermejo, P.; Alcami, J. Screening of South American plants against human immunodeficiency virus: Preliminary fractionation of aqueous extract from Baccharis trinervis. Biol. Pharm. Bull. 2002, 25, 1147-1150. [CrossRef]

121. Rezazadeh, F.; Moshaverinia, M.; Motamedifar, M.; Alyaseri, M. Assessment of anti HSV-1 activity of Aloe vera gel extract: An in vitro study. J. Dent. 2016, 17, 49.

122. Padma, P.; Pramod, N.; Thyagarajan, S.; Khosa, R. Effect of the extract of Annona muricata and Petunia nyctaginiflora on Herpes simplex virus. J. Ethnopharmacol. 1998, 61, 81-83. [CrossRef]

123. Andrighetti-Fröhner, C.; Sincero, T.; Da Silva, A.; Savi, L.; Gaido, C.; Bettega, J.; Mancini, M.; De Almeida, M.; Barbosa, R.; Farias, M. Antiviral evaluation of plants from Brazilian atlantic tropical forest. Fitoterapia 2005, 76, 374-378. [CrossRef]

124. Zaharieva, M.M.; Genova-Kalou, P.; Dincheva, I.; Badjakov, I.; Krumova, S.; Enchev, V.; Najdenski, H.; Markova, N. Anti-Herpes Simplex virus and antibacterial activities of Graptopetalum paraguayense E. Walther leaf extract: A pilot study. Biotechnol. Biotechnol. Equip. 2019, 33, 1251-1259. [CrossRef]

125. Bisignano, C.; Mandalari, G.; Smeriglio, A.; Trombetta, D.; Pizzo, M.M.; Pennisi, R.; Sciortino, M.T. Almond skin extracts abrogate HSV-1 replication by blocking virus binding to the cell. Viruses 2017, 9, 178. [CrossRef]

126. Churqui, M.P.; Lind, L.; Thörn, K.; Svensson, A.; Savolainen, O.; Aranda, K.T.; Eriksson, K. Extracts of Equisetum giganteum $\mathrm{L}$ and Copaifera reticulate Ducke show strong antiviral activity against the sexually transmitted pathogen herpes simplex virus type 2. J. Ethnopharmacol. 2018, 210, 192-197. [CrossRef] [PubMed]

127. Nocchi, S.R.; Companhoni, M.V.P.; de Mello, J.C.P.; Dias Filho, B.P.; Nakamura, C.V.; Carollo, C.A.; Silva, D.B.; Ueda-Nakamura, T. Antiviral activity of crude hydroethanolic extract from Schinus terebinthifolia against Herpes simplex Virus Type 1. Planta Med. 2017, 234, 509-518. [CrossRef]

128. Hinkov, A.; Angelova, P.; Marchev, A.; Hodzhev, Y.; Tsvetkov, V.; Dragolova, D.; Todorov, D.; Shishkova, K.; Kapchina-Toteva, V.; Blundell, R. Nepeta nuda ssp. nuda L. water extract: Inhibition of replication of some strains of human alpha herpes virus (genus simplex virus) in vitro, mode of action and NMR-based metabolomics. J. Herb. Med. 2020, 21, 100334. [CrossRef]

129. Lavoie, S.; Côté, I.; Pichette, A.; Gauthier, C.; Ouellet, M.; Nagau-Lavoie, F.; Mshvildadze, V.; Legault, J. Chemical composition and anti-herpes simplex virus type 1 (HSV-1) activity of extracts from Cornus canadensis. BMC Complement. Altern. Med. 2017, 17, 123. [CrossRef]

130. Boff, L.; Silva, I.; Argenta, D.; Farias, L.; Alvarenga, L.; Pádua, R.; Braga, F.; Leite, J.; Kratz, J.; Simões, C. Strychnos pseudoquina A. St. Hil.: A Brazilian medicinal plant with promising in vitro antiherpes activity. J. Appl. Microbiol. 2016, 121, 1519-1529. [CrossRef]

131. Siqueira, E.M.d.S.; Lima, T.L.; Boff, L.; Lima, S.G.; Lourenço, E.M.; Ferreira, É.G.; Barbosa, E.G.; Machado, P.R.; Farias, K.J.; Ferreira, L.D.S. Antiviral Potential of Spondias mombin L. Leaves Extract Against Herpes Simplex Virus Type-1 Replication Using In Vitro and In Silico Approaches. Planta Med. 2020, 86, 505-515. [CrossRef]

132. Di Sotto, A.; Di Giacomo, S.; Amatore, D.; Locatelli, M.; Vitalone, A.; Toniolo, C.; Rotino, G.L.; Lo Scalzo, R.; Palamara, A.T.; Marcocci, M.E. A polyphenol rich extract from Solanum melongena L. DR2 peel exhibits antioxidant properties and anti-Herpes Simplex Virus Type 1 activity in vitro. Molecules 2018, $23,2066$. [CrossRef]

133. Wang, Y.-Q.; Cai, L.; Zhang, N.; Zhang, J.; Wang, H.-H.; Zhu, W. Protective effect of total flavonoids from Ixeris Sonchifolia on herpes simplex virus keratitis in mice. BMC Complement. Med. Ther. 2020, 20, 1-8. [CrossRef] [PubMed]

134. Nawawi, A.A.; Nakamura, N.; Hattori, M.; Kurokawa, M.; Shiraki, K. Inhibitory effects of Indonesian medicinal plants on the infection of herpes simplex virus type 1. Phytother. Res. Int. J. Devoted Pharmacol. Toxicol. Eval. Nat. Prod. Deriv. 1999, 13,37-41. [CrossRef] 
135. Benzekri, R.; Bouslama, L.; Papetti, A.; Hammami, M.; Smaoui, A.; Limam, F. Anti HSV-2 activity of Peganum harmala (L.) and isolation of the active compound. Microb. Pathog. 2018, 114, 291-298. [CrossRef] [PubMed]

136. Ben Sassi, A.; Harzallah-Skhiri, F.; Bourgougnon, N.; Aouni, M. Antiviral activity of some Tunisian medicinal plants against Herpes simplex virus type 1. Nat. Prod. Res. 2008, 22, 53-65. [CrossRef]

137. Gavanji, S.; Sayedipour, S.S.; Larki, B.; Bakhtari, A. Antiviral activity of some plant oils against herpes simplex virus type 1 in Vero cell culture. J. Acute Med. 2015, 5, 62-68. [CrossRef]

138. Donalisio, M.; Cagno, V.; Civra, A.; Gibellini, D.; Musumeci, G.; Rittà, M.; Ghosh, M.; Lembo, D. The traditional use of Vachellia nilotica for sexually transmitted diseases is substantiated by the antiviral activity of its bark extract against sexually transmitted viruses. J. Ethnopharmacol. 2018, 213, 403-408. [CrossRef]

139. Nakamura, N.; Hattori, M.; Kurokawa, M.; Shiraki, K.; Kashiwaba, N.; Ono, M. Anti-herpes simplex virus activity of alkaloids isolated from Stephania cepharantha. Biol. Pharm. Bull. 1999, 22, 268-274.

140. Ghosh, M.; Civra, A.; Rittà, M.; Cagno, V.; Mavuduru, S.G.; Awasthi, P.; Lembo, D.; Donalisio, M. Ficus religiosa L. bark extracts inhibit infection by herpes simplex virus type 2 in vitro. Arch. Virol. 2016, 161, 3509-3514. [CrossRef]

141. Verma, H.; Patil, P.; Kolhapure, R.; Gopalkrishna, V. Antiviral activity of the Indian medicinal plant extract, Swertia chirata against herpes simplex viruses: A study by in-vitro and molecular approach. Indian J. Med Microbiol. 2008, 26, 322.

142. Hayashi, K.; Niwayama, S.; Hayashi, T.; Nago, R.; Ochiai, H.; Morita, N. In vitro and in vivo antiviral activity of scopadulcic acid B from Scoparia dulcis, Scrophulariaceae, against herpes simplex virus type 1. Antivir. Res. 1988, 9, 345-354. [CrossRef]

143. Ojha, D.; Das, R.; Sobia, P.; Dwivedi, V.; Ghosh, S.; Samanta, A.; Chattopadhyay, D. Pedilanthus tithymaloides inhibits HSV infection by modulating NF-kB signaling. PLoS ONE 2015, 10, e0139338. [CrossRef] [PubMed]

144. Wiart, C.; Kumar, K.; Yusof, M.; Hamimah, H.; Fauzi, Z.; Sulaiman, M. Antiviral properties of ent-labdene diterpenes of Andrographis paniculata Nees, inhibitors of herpes simplex virus type 1. Phytother. Res. Int. J. Devoted Pharmacol. Toxicol. Eval. Nat. Prod. Deriv. 2005, 19, 1069-1070.

145. Hafidh, R.R.; Abdulamir, A.S.; Bakar, F.A.; Sekawi, Z.; Jahansheri, F.; Jalilian, F.A. Novel antiviral activity of mung bean sprouts against respiratory syncytial virus and herpes simplex virus-1: An in vitro study on virally infected Vero and MRC-5 cell lines. BMC Complement. Altern. Med. 2015, 15, 179. [CrossRef]

146. Karimi, A.; Moradi, M.-T.; Saeedi, M.; Asgari, S.; Rafieian-Kopaei, M. Antiviral activity of Quercus persica L.: High efficacy and low toxicity. Adv. Biomed. Res. 2013, 2, 36.

147. Elanchezhiyan, M.; Rajarajan, S.; Rajendran, P.; Subramanian, S.; Thyagarajan, S. Antiviral properties of the seed extract of an Indian medicinal plant, Pongamia pinnata, Linn., against herpes simplex viruses: In-vitro studies on Vero cells. J. Med. Microbiol. 1993, 38, 262-264. [CrossRef]

148. Cheng, H.-Y.; Lin, T.-C.; Yang, C.-M.; Wang, K.-C.; Lin, C.-C. Mechanism of action of the suppression of herpes simplex virus type 2 replication by pterocarnin A. Microbes Infect. 2004, 6, 738-744. [CrossRef]

149. Namazi, R.; Zabihollahi, R.; Behbahani, M.; Rezaei, A. Inhibitory activity of Avicennia marina, a medicinal plant in Persian folk medicine, against HIV and HSV. Iran. J. Pharm. Res. IJPR 2013, 12, 435.

150. Jadhav, P.; Kapoor, N.; Thomas, B.; Lal, H.; Kshirsagar, N. Antiviral potential of selected Indian medicinal (ayurvedic) plants against herpes simplex virus 1 and 2. N. Am. J. Med Sci. 2012, 4, 641. [CrossRef]

151. Jaime, M.F.V.; Redko, F.; Muschietti, L.V.; Campos, R.H.; Martino, V.S.; Cavallaro, L.V. In vitro antiviral activity of plant extracts from Asteraceae medicinal plants. Virol. J. 2013, 10, 245. [CrossRef]

152. Lin, L.-C.; Kuo, Y.-C.; Chou, C.-J. Anti-herpes simplex virus type-1 flavonoids and a new flavanone from the root of Limonium sinense. Planta Med. 2000, 66, 333-336. [CrossRef]

153. Zhang, Y.; But, P.P.-H.; Ooi, V.E.-C.; Xu, H.-X.; Delaney, G.D.; Lee, S.H.; Lee, S.F. Chemical properties, mode of action, and in vivo anti-herpes activities of a lignin—carbohydrate complex from Prunella vulgaris. Antivir. Res. 2007, 75, 242-249. [CrossRef] [PubMed]

154. Konigheim, B.S.; Beranek, M.; Comini, L.R.; Aguilar, J.J.; Marioni, J.; Cabrera, J.L.; Contigiani, M.S.; Montoya, S.C.N. In Vitro antiviral activity of Heterophyllaea pustulata extracts. Nat. Prod. Commun. 2012, 7, 1025-1028. [CrossRef]

155. Lin, Y.-M.; Flavin, M.T.; Schure, R.; Chen, F.-C.; Sidwell, R.; Barnard, D.I.; Huffmann, J.H.; Kern, E.R. Antiviral activities of biflavonoids. Planta Med. 1999, 65, 120-125. [CrossRef] [PubMed] 
156. Martin, S.F. The amaryllidaceae alkaloids. In The Alkaloids: Chemistry and Pharmacology; Elsevier: Amsterdam, The Netherlands, 1987; Volume 30, pp. 251-376.

157. Bourne, K.Z.; Bourne, N.; Reising, S.F.; Stanberry, L.R. Plant products as topical microbicide candidates: Assessment of in vitro and in vivo activity against herpes simplex virus type 2 . Antivir. Res. 1999, 42, $219-226$. [CrossRef]

158. Andersen, D.O.; Weber, N.D.; Wood, S.G.; Hughes, B.G.; Murray, B.K.; North, J.A. In vitro virucidal activity of selected anthraquinones and anthraquinone derivatives. Antivir. Res. 1991, 16, 185-196. [CrossRef]

159. Chokchaisiri, R.; Srijun, J.; Chaichompoo, W.; Cheenpracha, S.; Ganranoo, L.; Suksamrarn, A. Anti-herpes simplex type-1 (HSV-1) activity from the roots of Jatropha multifida L. Med. Chem. Res. 2020, 29, 328-333. [CrossRef]

160. Killingley, B.; Greatorex, J.; Cauchemez, S.; Enstone, J.; Curran, M.; Read, R.; Lim, W.; Hayward, A.; Nicholson, K.; Nguyen-Van-Tam, J. Virus shedding and environmental deposition of novel A (H1N1) pandemic influenza virus: Interim findings. Health Technol Assess 2010, 14, 237-354. [CrossRef]

161. Simonsen, L.; Clarke, M.J.; Schonberger, L.B.; Arden, N.H.; Cox, N.J.; Fukuda, K. Pandemic versus epidemic influenza mortality: A pattern of changing age distribution. J. Infect. Dis. 1998, 178, 53-60. [CrossRef]

162. Jester, B.J.; Uyeki, T.M.; Jernigan, D.B. Fifty Years of Influenza A (H3N2) Following the Pandemic of 1968. Am. J. Public Health 2020, 110, 669-676. [CrossRef]

163. Xue, L.; Zeng, G. An Evaluation of China's Influenza A (H1N1) Emergency Response Measures. In $A$ Comprehensive Evaluation on Emergency Response in China; Springer: Singapore, 2019; pp. 107-158.

164. Dixit, R. Influenza in Vulnerable Populations. PhD Thesis, Faculty of Medicine, Sydney University, Sydney, Australia, 2018.

165. Chow, A.; Ma, S.; Ling, A.E.; Chew, S.K. Influenza-associated deaths in tropical Singapore. Emerg. Infect. Dis. 2006, 12, 114. [CrossRef]

166. Taubenberger, J.K.; Kash, J.C. Influenza virus evolution, host adaptation, and pandemic formation. Cell Host Microbe 2010, 7, 440-451. [CrossRef]

167. Chandler, J.D.; Hu, X.; Ko, E.-J.; Park, S.; Fernandes, J.; Lee, Y.-T.; Orr, M.L.; Hao, L.; Smith, M.R.; Neujahr, D.C. Low-dose cadmium potentiates lung inflammatory response to 2009 pandemic H1N1 influenza virus in mice. Environ. Int. 2019, 127, 720-729. [CrossRef]

168. Su, S.; Gu, M.; Liu, D.; Cui, J.; Gao, G.F.; Zhou, J.; Liu, X. Epidemiology, evolution, and pathogenesis of H7N9 influenza viruses in five epidemic waves since 2013 in China. Trends Microbiol. 2017, 25, 713-728. [CrossRef]

169. Nachbagauer, R.; Krammer, F. Universal influenza virus vaccines and therapeutic antibodies. Clin. Microbiol. Infect. 2017, 23, 222-228. [CrossRef] [PubMed]

170. Zhang, T.; Yin, C.; Boyd, D.F.; Quarato, G.; Ingram, J.P.; Shubina, M.; Ragan, K.B.; Ishizuka, T.; Crawford, J.C.; Tummers, B. Influenza virus Z-RNAs induce ZBP1-mediated necroptosis. Cell 2020, 180, 1115-1129. [CrossRef]

171. Jang, Y.; Jin, M.; Seo, S.H. Histamine contributes to severe pneumonia in pigs infected with 2009 pandemic H1N1 influenza virus. Arch. Virol. 2018, 163, 3015-3022. [CrossRef] [PubMed]

172. Ng, S.; Nachbagauer, R.; Balmaseda, A.; Stadlbauer, D.; Ojeda, S.; Patel, M.; Rajabhathor, A.; Lopez, R.; Guglia, A.F.; Sanchez, N. Novel correlates of protection against pandemic H1N1 influenza A virus infection. Nat. Med. 2019, 25, 962-967. [CrossRef] [PubMed]

173. Lau, H.; Deng, Y.-M.; Xu, X.; Sessions, W.; Barr, I.G. Rapid detection of new B/Victoria-lineage haemagglutinin variants of influenza B viruses by pyrosequencing. Diagn. Microbiol. Infect. Dis. 2019, 93, 311-317. [CrossRef]

174. Chan, W.M.; Wong, L.H.; So, C.F.; Chen, L.L.; Wu, W.L.; Ip, J.D.; Lam, A.H.Y.; Yip, C.C.; Yuen, K.Y.; To, K.K. Development and evaluation of a conventional RT-PCR for differentiating emerging influenza B/Victoria lineage viruses with hemagglutinin amino acid deletion from B/Yamagata lineage viruses. J. Med Virol. 2019, 92, 382-385. [CrossRef]

175. DiPiazza, A.; Nogales, A.; Poulton, N.; Wilson, P.C.; Martínez-Sobrido, L.; Sant, A.J. Pandemic 2009 H1N1 Influenza Venus reporter virus reveals broad diversity of MHC class II-positive antigen-bearing cells following infection in vivo. Sci. Rep. 2017, 7, 10857. [CrossRef]

176. Reina, J.; Reina, N. Universal influenza vaccination: Future prospects. Vacunas (Engl. Ed.) 2019, $20,72-81$. [CrossRef]

177. Rafiq, D.; Batool, A.; Bazaz, M. Three months of COVID-19: A systematic review and meta-analysis. Rev. Med. Virol. 2020, 30, e2113. [CrossRef] [PubMed] 
178. Glathe, H.; Hilgenfeld, M.; Lebhardt, A.; Strittmatter, H.; Schulze, P.; Brandt, B. The intestine of ferret-A possible site of influenza virus replication. Acta Virol. 1984, 28, 287.

179. Neumann, G.; Brownlee, G.; Fodor, E.; Kawaoka, Y. Orthomyxovirus replication, transcription, and polyadenylation. In Biology of Negative Strand RNA Viruses: The Power of Reverse Genetics; Springer: Heidelberg, Germany, 2004; pp. 121-143.

180. Portela, A.; Zürcher, T.; Nieto, A.; Ortín, J. Replication of orthomyxoviruses. In Advances in Virus Research; Elsevier: Amsteerdam, The Netherlands, 1999; Volume 54, pp. 319-348.

181. Long, C. Challenging contingency: Viruses and the nature of molecular life. Secur. Dialogue 2019, 51, 323-339. [CrossRef]

182. Xue, L.; Zeng, G. Global Strategies and Response Measures to the Influenza A (H1N1) Pandemic. In $A$ Comprehensive Evaluation on Emergency Response in China; Springer: Singapore, 2019; pp. 15-44.

183. Kannan, S.; Kolandaivel, P. Antiviral potential of natural compounds against influenza virus hemagglutinin. Comput. Biol. Chem. 2017, 71, 207-218. [CrossRef]

184. Tochino, Y.; Fujioka, M.; Sakazaki, H.; Ikuno, Y.; Tochino, R.; Yoshii, N.; Shintaku, H.; Hirata, K. Current usage and effectiveness of influenza medications and factors regarding the time taken to alleviate fever based on postcard questionnaire survey. J. Gen. Fam. Med. 2017, 18, 386-392. [CrossRef] [PubMed]

185. Paul, D.; Bartenschlager, R. Architecture and biogenesis of plus-strand RNA virus replication factories. World J. Virol. 2013, 2, 32. [CrossRef]

186. Ludwig, S.; Planz, O.; Pleschka, S.; Wolff, T. Influenza-virus-induced signaling cascades: Targets for antiviral therapy? Trends Mol. Med. 2003, 9, 46-52. [CrossRef]

187. Garman, E.; Laver, G. Controlling influenza by inhibiting the virus's neuraminidase. Curr. Drug Targets 2004, 5, 119-136. [CrossRef]

188. Müller, B.; Kräusslich, H.-G. Antiviral strategies. In Antiviral Strategies; Springer: Singapore, 2009; pp. 1-24.

189. Weiss, G.; Schaible, U.E. Macrophage defense mechanisms against intracellular bacteria. Immunol. Rev. 2015, 264, 182-203. [CrossRef]

190. Wang, X.; Jia, W.; Zhao, A.; Wang, X. Anti-influenza agents from plants and traditional Chinese medicine. Phytother. Res. 2006, 20, 335-341. [CrossRef] [PubMed]

191. Droebner, K.; Ehrhardt, C.; Poetter, A.; Ludwig, S.; Planz, O. CYSTUS052, a polyphenol-rich plant extract, exerts anti-influenza virus activity in mice. Antivir. Res. 2007, 76, 1-10. [CrossRef] [PubMed]

192. Ji Na, W.; Seo Yong, L.; Dae Sub, S.; Har Young, P. Antiviral Activity of the Plant Extracts from Thuja orientalis, Aster spathulifolius, and Pinus thunbergii Against Influenza Virus A/PR/8/34. J. Microbiol. Biotechnol. 2013, 23, 125-130.

193. GabAllah, M.; Kandeil, A.; Mousa, A.E.-B.; Ahmed Ali, M. Antiviral activity of water extracts of some medicinal and nutritive plants from the Apiaceae family. Nov. Res. Microbiol. J. 2020, 4, 725-735. [CrossRef]

194. Ombito, J.O.; Salano, E.N.; Yegon, P.K.; Ngetich, W.K.; Mwangi, E.M.; Koe, G. A review of the chemistry of some species of genus Aloe (Xanthorrhoeaceae family). J. Sci. Innov. Res. 2015, 4, 49-53.

195. Moradi, M.-T.; Karimi, A.; Shahrani, M.; Hashemi, L.; Ghaffari-Goosheh, M.-S. Anti-Influenza Virus Activity and Phenolic Content of Pomegranate (Punica granatum L.) Peel Extract and Fractions. Avicenna J. Med. Biotechnol. 2019, 11, 285-291.

196. Choi, J.-G.; Kim, Y.S.; Kim, J.H.; Chung, H.-S. Antiviral activity of ethanol extract of Geranii Herba and its components against influenza viruses via neuraminidase inhibition. Sci. Rep. 2019, 9, 12132. [CrossRef]

197. Rajasekaran, D.; Palombo, E.A.; Chia Yeo, T.; Lim Siok Ley, D.; Lee Tu, C.; Malherbe, F.; Grollo, L. Identification of traditional medicinal plant extracts with novel anti-influenza activity. PLoS ONE 2013, 8, e79293. [CrossRef]

198. Tran, T.T.; Kim, M.; Jang, Y.; Lee, H.W.; Nguyen, H.T.; Nguyen, T.N.; Park, H.W.; Le Dang, Q.; Kim, J.-C. Characterization and mechanisms of anti-influenza virus metabolites isolated from the Vietnamese medicinal plant Polygonum chinense. BMC Complement. Altern. Med. 2017, 17, 162. [CrossRef] [PubMed]

199. Shi, Y.; Zhang, B.; Lu, Y.; Qian, C.; Feng, Y.; Fang, L.; Ding, Z.; Cheng, D. Antiviral activity of phenanthrenes from the medicinal plant Bletilla striata against influenza A virus. BMC Complement. Altern. Med. 2017, 17, 273. [CrossRef]

200. Shoji, M.; Woo, S.-Y.; Masuda, A.; Win, N.N.; Ngwe, H.; Takahashi, E.; Kido, H.; Morita, H.; Ito, T.; Kuzuhara, T. Anti-influenza virus activity of extracts from the stems of Jatropha multifida Linn. collected in Myanmar. BMC Complement. Altern. Med. 2017, 17, 96. [CrossRef] 
201. He, W.; Han, H.; Wang, W.; Gao, B. Anti-influenza virus effect of aqueous extracts from dandelion. Virol. J. 2011, 8, 538. [CrossRef]

202. Zhang, T.; Lo, C.-Y.; Xiao, M.; Cheng, L.; Pun Mok, C.K.; Shaw, P.-C. Anti-influenza virus phytochemicals from Radix Paeoniae Alba and characterization of their neuraminidase inhibitory activities. J. Ethnopharmacol. 2020, 253, 112671. [CrossRef] [PubMed]

203. Mohamed, M.S.; Idriss, M.T.; Alruwaili, N.K.; Alotaibi, N.H.; Elsaman, T.; Mohamed, M.A. Investigation of the potential anti-influenza activity of five plants grown in Sudan and used folklorically for respiratory infections. J. Appl. Pharm. Sci. 2020, 10, 054-061.

204. Moradi, M.-T.; Karimi, A.; Rafieian-Kopaei, M.; Rabiei-Faradonbeh, M.; Momtaz, H. Pomegranate peel extract inhibits internalization and replication of the influenza virus: An in vitro study. Avicenna J. Phytomed. 2020, 10, 143-151.

205. Zhang, L.; Chen, J.; Ke, C.; Zhang, H.; Zhang, S.; Tang, W.; Liu, C.; Liu, G.; Chen, S.; Hu, A.; et al. Ethanol Extract of Caesalpinia decapetala Inhibits Influenza Virus Infection In Vitro and In Vivo. Viruses 2020, $12,557$. [CrossRef]

206. Brown, E. Influenza virus genetics. Biomed. Pharm. 2000, 54, 196-209. [CrossRef]

207. Ghildiyal, R.; Prakash, V.; Chaudhary, V.; Gupta, V.; Gabrani, R. Phytochemicals as Antiviral Agents: Recent Updates. In Plant-Derived Bioactives; Springer: Singapore, 2020; pp. 279-295.

208. Moradi, M.-T.; Karimi, A.; Lorigooini, Z. Alkaloids as the natural anti-influenza virus agents: A systematic review. Toxin Rev. 2018, 37, 11-18. [CrossRef]

209. Hazra, S.; Chattopadhyay, S. An overview of lignans with special reference to podophyllotoxin, a cytotoxic lignan. Chem. Biol. Lett. 2016, 3, 1-8.

210. Kazakova, O.; Smirnova, I.; Baltina, L.; Boreko, E.; Savinova, O.; Pokrovskii, A. Antiviral activity of acyl derivatives of betulin and betulinic and dihydroquinopimaric acids. Russ. J. Bioorganic Chem. 2018, 44, 740-744. [CrossRef]

211. Liu, G.; Xiong, S.; Xiang, Y.-F.; Guo, C.-W.; Ge, F.; Yang, C.-R.; Zhang, Y.-J.; Wang, Y.-F.; Kitazato, K. Antiviral activity and possible mechanisms of action of pentagalloylglucose (PGG) against influenza A virus. Arch Virol. 2011, 156, 1359-1369. [CrossRef] [PubMed]

212. Wu, W.; Li, R.; Li, X.; He, J.; Jiang, S.; Liu, S.; Yang, J. Quercetin as an antiviral agent inhibits influenza A virus (IAV) entry. Viruses 2016, 8, 6. [CrossRef]

213. Sithisarn, P.; Michaelis, M.; Schubert-Zsilavecz, M.; Cinatl Jr, J. Differential antiviral and anti-inflammatory mechanisms of the flavonoids biochanin A and baicalein in H5N1 influenza A virus-infected cells. Antivir. Res. 2013, 97, 41-48. [CrossRef]

214. Bang, S.; Ha, T.K.Q.; Lee, C.; Li, W.; Oh, W.-K.; Shim, S.H. Antiviral activities of compounds from aerial parts of Salvia plebeia R. Br. J. Ethnopharmacol. 2016, 192, 398-405. [CrossRef] [PubMed]

215. Zhang, G.; Zhang, B.; Zhang, X.; Bing, F. Homonojirimycin, an alkaloid from dayflower inhibits the growth of influenza A virus in vitro. Acta Virol. 2013, 57, 85-86. [CrossRef] [PubMed]

216. Li, R.; Liu, T.; Liu, M.; Chen, F.; Liu, S.; Yang, J. Anti-influenza A virus activity of dendrobine and its mechanism of action. J. Agric. Food Chem. 2017, 65, 3665-3674. [CrossRef]

217. Soriano, V.; Vispo, E.; Poveda, E.; Labarga, P.; Martin-Carbonero, L.; Fernandez-Montero, J.V.; Barreiro, P. Directly acting antivirals against hepatitis C virus. J. Antimicrob. Chemother. 2011, 66, 1673-1686. [CrossRef]

218. Smyth, B.; O'Connor, J.; Barry, J.; Keenan, E. Retrospective cohort study examining incidence of HIV and hepatitis C infection among injecting drug users in Dublin. J. Epidemiol. Community Health 2003, 57, 310-311. [CrossRef]

219. Kurniawan, J. Pangenotypic Direct Acting Antivirals Treatment for Chronic Hepatitis C Infection. Indones. J. Gastroenterol. Hepatol. Dig. Endosc. 2020, 21, 1-2. [CrossRef]

220. Pietri, O.; Trottier-Tellier, F.; Bourlière, M. While direct-acting antivirals are effective, are there any unique safety considerations? Clin. Dilemmas in Viral Liver Dis. 2020, 97-105.

221. Agnello, V.; Ábel, G.; Elfahal, M.; Knight, G.B.; Zhang, Q.-X. Hepatitis C virus and other flaviviridae viruses enter cells via low density lipoprotein receptor. Proc. Natl. Acad. Sci. USA 1999, 96, 12766-12771. [PubMed]

222. Lindenbach, B.D.; Rice, C.M. Unravelling hepatitis $C$ virus replication from genome to function. Nature 2005, 436, 933-938. [CrossRef] [PubMed] 
223. Denaro, M.; Smeriglio, A.; Barreca, D.; De Francesco, C.; Occhiuto, C.; Milano, G.; Trombetta, D. Antiviral activity of plants and their isolated bioactive compounds: An update. Phytother. Res. 2020, 34, 742-768. [PubMed]

224. Yousaf, T.; Rafique, S.; Wahid, F.; Rehman, S.; Nazir, A.; Rafique, J.; Aslam, K.; Shabir, G.; Shah, S.M. Phytochemical profiling and antiviral activity of Ajuga bracteosa, Ajuga parviflora, Berberis lycium and Citrus lemon against Hepatitis C Virus. Microb. Pathog. 2018, 118, 154-158. [CrossRef] [PubMed]

225. Wahyuni, T.S.; Tumewu, L.; Permanasari, A.A.; Apriani, E.; Adianti, M.; Rahman, A.; Widyawaruyanti, A.; Lusida, M.I.; Fuad, A.; Fuchino, H. Antiviral activities of Indonesian medicinal plants in the East Java region against hepatitis C virus. Virol. J. 2013, 10, 259. [PubMed]

226. Ravikumar, Y.; Ray, U.; Nandhitha, M.; Perween, A.; Naika, H.R.; Khanna, N.; Das, S. Inhibition of hepatitis C virus replication by herbal extract: Phyllanthus amarus as potent natural source. Virus Res. 2011, 158, 89-97.

227. Hussein, G.; Miyashiro, H.; Nakamura, N.; Hattori, M.; Kakiuchi, N.; Shimotohno, K. Inhibitory effects of Sudanese medicinal plant extracts on hepatitis $\mathrm{C}$ virus $(\mathrm{HCV})$ protease. Phytother. Res. Int. J. Devoted Pharmacol. Toxicol. Eval. Nat. Prod. Deriv. 2000, 14, 510-516. [CrossRef]

228. Ratnoglik, S.L.; Aoki, C.; Sudarmono, P.; Komoto, M.; Deng, L.; Shoji, I.; Fuchino, H.; Kawahara, N.; Hotta, H. Antiviral activity of extracts from Morinda citrifolia leaves and chlorophyll catabolites, pheophorbide a and pyropheophorbide a, against hepatitis C virus. Microbiol. Immunol. 2014, 58, 188-194.

229. Wagoner, J.; Negash, A.; Kane, O.J.; Martinez, L.E.; Nahmias, Y.; Bourne, N.; Owen, D.M.; Grove, J.; Brimacombe, C.; McKeating, J.A. Multiple effects of silymarin on the hepatitis C virus lifecycle. Hepatology 2010, 51, 1912-1921. [CrossRef]

230. Hsu, W.-C.; Chang, S.-P.; Lin, L.-C.; Li, C.-L.; Richardson, C.D.; Lin, C.-C.; Lin, L.-T. Limonium sinense and gallic acid suppress hepatitis $C$ virus infection by blocking early viral entry. Antivir. Res. 2015, 118, 139-147. [CrossRef]

231. Yang, X.-Y.; Zhang, Y.-Y.; Xie, W.-R.; He, S.H.; Wu, L.-H.; He, X.-X.; Xia, H.H.-X. Herbal Medicines for Hepatitis C Virus Infection: The Exploratory Journey from Bench to Bedside Still Has a Long Way to Go. J. Explor. Res. Pharmacol. 2019, 4, 9-18. [CrossRef]

232. Hung, T.-C.; Jassey, A.; Lin, C.-J.; Liu, C.-H.; Lin, C.-C.; Yen, M.-H.; Lin, L.-T. Methanolic extract of Rhizoma Coptidis inhibits the early viral entry steps of hepatitis C virus infection. Viruses 2018, 10, 669. [CrossRef] [PubMed]

233. Javed, T.; Ashfaq, U.A.; Riaz, S.; Rehman, S.; Riazuddin, S. In-vitro antiviral activity of Solanum nigrum against Hepatitis C Virus. Virol. J. 2011, 8, 26. [CrossRef] [PubMed]

234. Bachmetov, L.; Gal-Tanamy, M.; Shapira, A.; Vorobeychik, M.; Giterman-Galam, T.; Sathiyamoorthy, P.; Golan-Goldhirsh, A.; Benhar, I.; Tur-Kaspa, R.; Zemel, R. Suppression of hepatitis C virus by the flavonoid quercetin is mediated by inhibition of NS3 protease activity. J. Viral Hepat. 2012, 19, e81-e88. [CrossRef]

235. Lin, C.-W.; Lo, C.-W.; Tsai, C.-N.; Pan, T.-C.; Chen, P.-Y.; Yu, M.-J. Aeginetia indica decoction inhibits hepatitis C virus life cycle. Int. J. Mol. Sci. 2018, 19, 208. [CrossRef]

236. Zuo, G.; Li, Z.; Chen, L.; Xu, X. Activity of compounds from Chinese herbal medicine Rhodiola kirilowii (Regel) Maxim against HCV NS3 serine protease. Antivir. Res. 2007, 76, 86-92. [CrossRef]

237. Qian, X.-J.; Zhang, X.-L.; Zhao, P.; Jin, Y.-S.; Chen, H.-S.; Xu, Q.-Q.; Ren, H.; Zhu, S.-Y.; Tang, H.-L.; Zhu, Y.-Z. A Schisandra-derived compound schizandronic acid inhibits entry of Pan-HCV genotypes into human hepatocytes. Sci. Rep. 2016, 6, 27268. [CrossRef]

238. Chen, S.-R.; Wang, A.-Q.; Lin, L.-G.; Qiu, H.-C.; Wang, Y.-T.; Wang, Y. In vitro study on anti-hepatitis C virus activity of Spatholobus suberectus Dunn. Molecules 2016, 21, 1367. [CrossRef]

239. Lee, S.; Yoon, K.D.; Lee, M.; Cho, Y.; Choi, G.; Jang, H.; Kim, B.; Jung, D.H.; Oh, J.G.; Kim, G.W. Identification of a resveratrol tetramer as a potent inhibitor of hepatitis $C$ virus helicase. Br. J. Pharm. 2016, 173, 191-211. [CrossRef]

240. Li, S.; Kodama, E.N.; Inoue, Y.; Tani, H.; Matsuura, Y.; Zhang, J.; Tanaka, T.; Hattori, T. Procyanidin B1 purified from Cinnamomi cortex suppresses hepatitis $C$ virus replication. Antivir. Chem. Chemother. 2010, 20, 239-248. [CrossRef]

241. Sola, M.A.W.M.; Permanasari, A.A.; Adianti, M.; Tumewu, L.; Widyawaruyanti, A.; Hafid, A.F. The Activity of Sterculia quadrifida R. br Stembark against Hepatitis C Virus. In Proceedings of the BROMO Conference (BROMO 2018), East Java, Indonesia, 11-12 July 2018; pp. 106-110. [CrossRef] 
242. Wagoner, J.; Morishima, C.; Graf, T.N.; Oberlies, N.H.; Teissier, E.; Pécheur, E.-I.; Tavis, J.E.; Polyak, S.J. Differential in vitro effects of intravenous versus oral formulations of silibinin on the HCV life cycle and inflammation. PLoS ONE 2011, 6, e16464. [CrossRef] [PubMed]

243. Poon, T.Y.C.; Ong, K.L.; Cheung, B.M.Y. Review of the effects of the traditional Chinese medicine Rehmannia Six Formula on diabetes mellitus and its complications. J. Diabetes 2011, 3, 184-200. [CrossRef] [PubMed]

244. Nahmias, Y.; Goldwasser, J.; Casali, M.; Van Poll, D.; Wakita, T.; Chung, R.T.; Yarmush, M.L. Apolipoprotein B-dependent hepatitis $C$ virus secretion is inhibited by the grapefruit flavonoid naringenin. Hepatology 2008, 47, 1437-1445. [CrossRef] [PubMed]

245. Lin, Y.-T.; Wu, Y.-H.; Tseng, C.-K.; Lin, C.-K.; Chen, W.-C.; Hsu, Y.-C.; Lee, J.-C. Green tea phenolic epicatechins inhibit hepatitis $C$ virus replication via cycloxygenase- 2 and attenuate virus-induced inflammation. PLOS ONE 2013, 8, e54466. [CrossRef] [PubMed]

246. Ashfaq, U.A.; Idrees, S. Medicinal plants against hepatitis C virus. World J. Gastroenterol. WJG 2014, $20,2941$. [CrossRef]

247. Liu, M.-M.; Zhou, L.; He, P.-L.; Zhang, Y.-N.; Zhou, J.-Y.; Shen, Q.; Chen, X.-W.; Zuo, J.-P.; Li, W.; Ye, D.-Y. Discovery of flavonoid derivatives as anti-HCV agents via pharmacophore search combining molecular docking strategy. Eur. J. Med. Chem. 2012, 52, 33-43. [CrossRef]

248. Lan, K.H.; Wang, Y.W.; Lee, W.P.; Lan, K.L.; Tseng, S.H.; Hung, L.R.; Yen, S.H.; Lin, H.C.; Lee, S.D. Multiple effects of Honokiol on the life cycle of hepatitis C virus. Liver Int. 2012, 32, 989-997. [CrossRef]

249. Wu, S.F.; Lin, C.K.; Chuang, Y.S.; Chang, F.R.; Tseng, C.K.; Wu, Y.C.; Lee, J.C. Anti-hepatitis C virus activity of 3-hydroxy caruilignan C from Swietenia macrophylla stems. J. Viral Hepat. 2012, 19, 364-370. [CrossRef]

250. Calland, N.; Sahuc, M.-E.; Belouzard, S.; Pène, V.; Bonnafous, P.; Mesalam, A.A.; Deloison, G.; Descamps, V.; Sahpaz, S.; Wychowski, C. Polyphenols inhibit hepatitis $C$ virus entry by a new mechanism of action. J. Virol. 2015, 89, 10053-10063. [CrossRef]

251. Lee, W.-P.; Lan, K.-L.; Liao, S.-X.; Huang, Y.-H.; Hou, M.-C.; Lan, K.-H. Inhibitory effects of amentoflavone and orobol on daclatasvir-induced resistance-associated variants of hepatitis C virus. Am. J. Chin. Med. 2018, 46, 835-852. [CrossRef]

252. Hassan, S.T.; Berchová-Bímová, K.; Petráš, J. Plumbagin, a Plant-Derived Compound, Exhibits Antifungal Combinatory Effect with Amphotericin B against Candida albicans Clinical Isolates and Anti-hepatitis C Virus Activity. Phytother. Res. 2016, 30, 1487-1492. [CrossRef] [PubMed]

253. Batista, M.N.; Carneiro, B.M.; Braga, A.C.S.; Rahal, P. Caffeine inhibits hepatitis C virus replication in vitro. Arch. Virol. 2015, 160, 399-407. [CrossRef] [PubMed]

254. Ma, C.-M.; Wei, Y.; Wang, Z.-G.; Hattori, M. Triterpenes from Cynomorium songaricium-Analysis of HCV protease inhibitory activity, quantification, and content change under the influence of heating. J. Nat. Med. 2009, 63, 9-14. [CrossRef] [PubMed]

Publisher's Note: MDPI stays neutral with regard to jurisdictional claims in published maps and institutional affiliations.

(C) 2020 by the authors. Licensee MDPI, Basel, Switzerland. This article is an open access article distributed under the terms and conditions of the Creative Commons Attribution (CC BY) license (http://creativecommons.org/licenses/by/4.0/). 